Research paper

\title{
Speculative petroleum systems of the southern Pelotas Basin, offshore Uruguay
}

\author{
Bruno Conti ${ }^{\mathrm{a}}$, , José Alexandre de Jesus Perinotto ${ }^{\mathrm{b}}$, Gerardo Veroslavsky ${ }^{\mathrm{c}}$, \\ María Gabriela Castillo ${ }^{\text {b }}$, Héctor de Santa Ana ${ }^{a}$, Matías Soto ${ }^{c}$, Ethel Morales ${ }^{c}$ \\ ${ }^{a}$ Exploration \& Production, ANCAP, Montevideo, Uruguay \\ ${ }^{\mathrm{b}}$ Universidade Estadual Paulista, Instituto de Geociências e Ciências Exatas, Rio Claro, Brazil \\ ${ }^{\mathrm{c}}$ Facultad de Ciencias, Instituto de Ciencias Geológicas, Uruguay
}

\section{A R T I C L E I N F O}

\section{Article history:}

Received 22 December 2015

Received in revised form

4 February 2017

Accepted 21 February 2017

Available online 2 March 2017

\section{Keywords:}

Sequence stratigraphy

Petroleum systems

Pelotas basin

Uruguayan atlantic margin

\begin{abstract}
A B S T R A C T
The Pelotas Basin of Brazil and Uruguay represents a frontier basin with under-explored hydrocarbon potential. Although oil and gas accumulations have yet to be identified, only 21 exploratory wells have been drilled in an area of more than $330,000 \mathrm{~km}^{2}, 20$ of which are located in the Brazilian portion of the basin. A detailed study of the petroleum system of offshore Uruguay has strong potential to contribute to a better characterization of the capacity of the basin to generate and accumulate hydrocarbons. Three stages have previously been recognized during the evolution of Pelotas basin: (1) a prerift phase which preserved Paleozoic and Mesozoic units of the Paraná Basin; (2) an Early Cretaceous volcanosedimentary synrift phase; and (3) a Cretaceous to Cenozoic postrift phase deposited during the passive margin stage. In this study, we use sequence stratigraphy methodology to interpret 2D multichannel seismic sections of the southern segment of the Pelotas Basin in the Uruguayan Atlantic margin. This analysis allows us to identify depositional sequences, systems tracts and the distribution of the main elements of the potential petroleum systems. Following our analysis, we propose six speculative petroleum systems (SPS) in the Pelotas Basin. The first SPS is related to the prerift phase and is represented by a Lower Permian restricted marine source rock and reservoirs related to Permian to Upper Jurassic aeolian and fluvial sandstones. The second SPS corresponds to the synrift phase and is constituted by a Barremian lacustrine source rock with reservoirs of alluvial/fluvial sandstones of the same age. The other four proposed SPS are associated with the postrift phase, represented by marine source rocks related to Aptian-Albian, Cenomanian-Turonian and Paleocene transgressions, all of which are identified in the region and interpreted in seismic lines from Uruguay. These postrift SPS have predominantly siliciclastic reservoirs represented by Early Cretaceous aeolian sandstones and Cretaceous to Cenozoic deltaic sandstones and turbidites.
\end{abstract}

(c) 2017 Elsevier Ltd. All rights reserved.

\section{Introduction}

The Pelotas Basin of Brazil and Uruguay formed during the fragmentation of the Gondwana supercontinent and subsequent opening of the South Atlantic Ocean from the Early Cretaceous onwards. The basin, with a total area of approximately $330,000 \mathrm{~km}^{2}$, extends with a NE-SW trend through the southern

\footnotetext{
* Corresponding author.

E-mail addresses: bconti@ancap.com.uy (B. Conti), perinoto@rc.unesp.br (J.A.J. Perinotto), gveroslavsky@gmail.com (G. Veroslavsky), mgcv@rc.unesp.br (M.G. Castillo), hdesantaana@ancap.com.uy (H. de Santa Ana), msoto@fcien.edu. uy (M. Soto), ethel@fcien.edu.uy (E. Morales).
}

Brazilian Atlantic margin, with its southernmost segment entering into the Uruguayan continental margin (Fig. 1). In its northeastern boundary in offshore Brazil, the Pelotas Basin borders with the Santos Basin through the Florianópolis High, whereas in its southwestern boundary in offshore Uruguay, it borders with the Punta del Este Basin through the Polonio High. As the Pelotas Basin developed mostly in the offshore region, its northwestern limit is bound by the eastern margin of the South American continent. An onshore segment of approximately $40,000 \mathrm{~km}^{2}$ formed in the nearshore area of Santa Catarina and Rio Grande do Sul states in the Brazilian segment. The southeastern margin of Pelotas Basin lies in ultradeep waters and is poorly defined due to the lack of seismic data in this region. The southeastern margin of the basin represents 


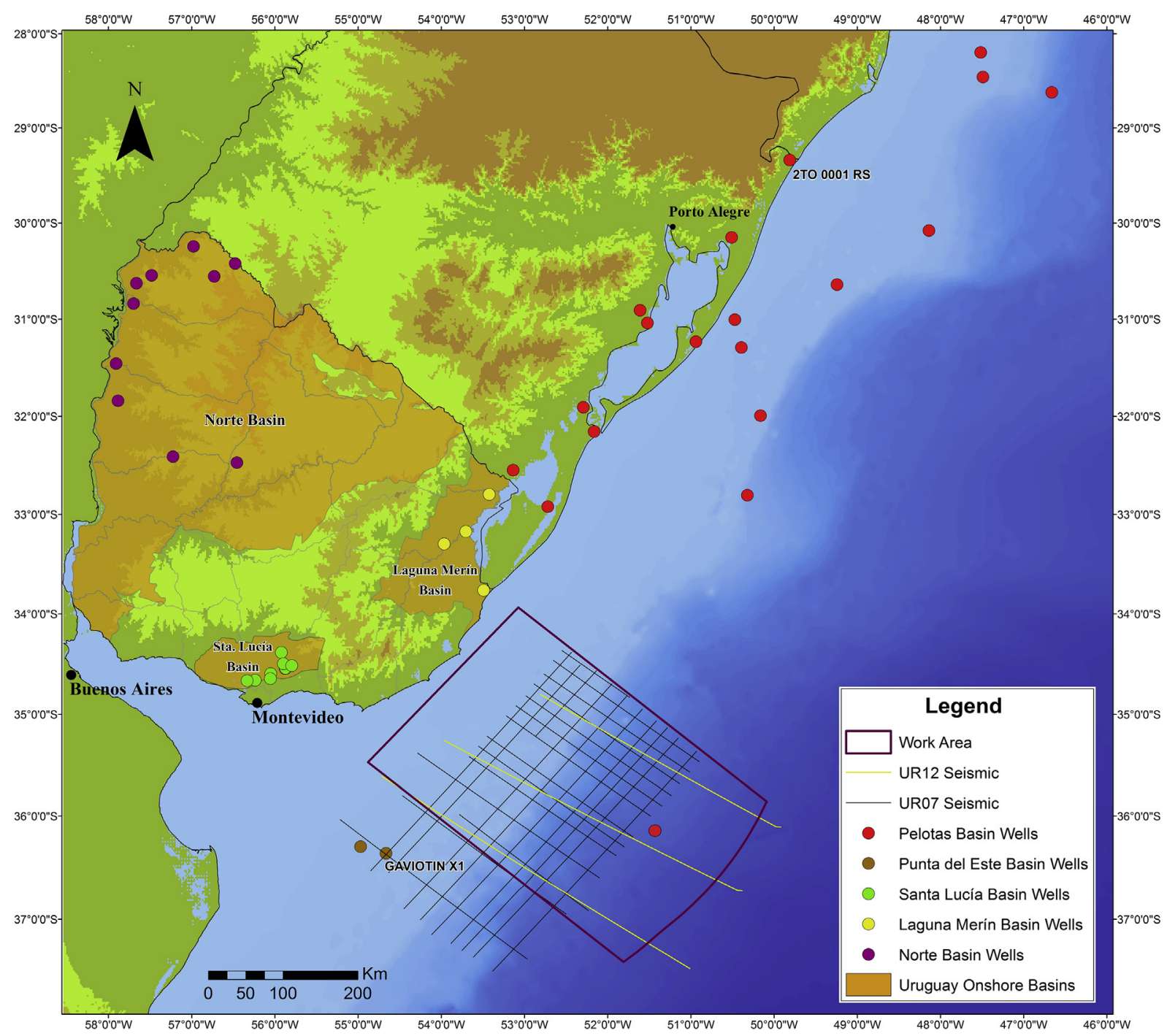

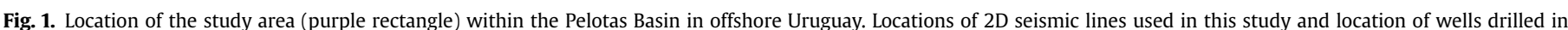

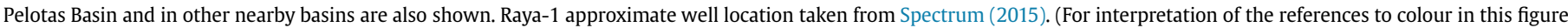
legend, the reader is referred to the web version of this article.)

a typical passive margin basin with a sigmoidal shape infill that thins out both in landward and seaward directions, where it overlays continental and oceanic crust, respectively.

Hydrocarbon accumulations have yet to be discovered in Pelotas Basin according with the exploratory information of the existing wells (ANP, 2015). However, much of the basin remains underexplored, especially the Uruguayan segment that counts with only one well drilled in 2016 in ultradeep waters. The Brazilian portion of Pelotas Basin has a total of 20 exploratory wells drilled in a surface area of $250,000 \mathrm{~km}^{2}$ (including bathymetry up to $3000 \mathrm{~m}$ ). These exploratory efforts began in the decades of 1950 and 1960 were 8 wells were drilled in the onshore area, based on gravity data. In the decade of 1970 the first seismic survey was acquired in the shelf region and 7 more wells were drilled in shallow waters. Other 5 wells were drilled in the offshore area between 1995 and 2001 (ANP, 2015). The study area (i.e., the Uruguayan segment of the basin), extends over $80,000 \mathrm{~km}^{2}$ in the central and northeastern part of the continental margin of Uruguay. Recently acquired 2D seismic data shows promising stratigraphic features in the Uruguayan portion of the basin, allowing us to identify potential source and reservoirs rocks in this area and mainly stratigraphic traps such as turbidites. These traps may be analogous to hydrocarbon accumulation found in other South Atlantic basins such as Campos and Santos (e.g., Cainelli and Mohriak, 1999). The aim of this work is to present an evaluation of the hydrocarbon potential of the Uruguayan portion of the Pelotas Basin, and to define its Speculative Petroleum System (SPS). Thus, we describe the seismostratigraphic interpretation of the prerift and synrift megasequences, as well as the depositional sequences/sucessions from the Cretaceous to Lower Paleocene postrift megasequence corresponding to the proposed petroleum systems.

\subsection{Study area}

For this study, we analyzed the southernmost portion of the Pelotas Basin in offshore Uruguay, located between the following parallels: $34^{\circ} 20^{\prime} \mathrm{S}$ and $36^{\circ} 40^{\prime} \mathrm{S}$, and the following meridians: $50^{\circ}$ $50^{\prime} \mathrm{W}$ and $52^{\circ} 50^{\prime} \mathrm{W}$ (Fig. 1 ).

\subsection{Materials and methods}

The database we used in this study consists of $6904 \mathrm{~km}$ of 2D multichannel seismic section data from the Uruguayan segment of 
Pelotas Basin (Fig. 1), of which $5904 \mathrm{~km}$ are property of the National Oil Company of Uruguay (ANCAP) and were acquired in 2007-2008 and 2011. The remaining $1042 \mathrm{~km}$ of $2 \mathrm{D}$ seismic data correspond to multiclient data acquired by ION-GXT in 2013. To visualize and interpret the database, we used Kingdom Suite software, version 8.8 (IHS). The Gaviotin x-1 well, located in shallow waters of the Punta del Este Basin, is the nearest well drilled (with available data for this work) to the study area and its biostratigraphic data was used to assign ages to the interpreted depositional sequences.

\subsection{Geological setting}

The Cretaceous breakup of the Gondwana supercontinent resulted in the formation of the South American and African tectonic plates. This process of continental fragmentation gave birth to the South Atlantic Ocean and a series of sedimentary basins located at the margins of both the South American and African continents. The rifting process began in the southern portion of Gondwana approximately $130 \mathrm{Ma}$ and propagated northward before the two continents were fully separated 20-30 m.y. later during AptianAlbian times (Bryant et al., 2012). Several of the rifts generated during this stage later evolved into passive margins including the Pelotas Basin (Porto and Asmus, 1976) in the southern segment of the Atlantic Ocean (Moulin et al., 2005). Two main stages typical of volcanic rifted margins are recognized within the structural evolution of the Pelotas Basin: synrift and postrift (also known as drift or passive margin).

In the proximal portion of Pelotas Basin a prerift megasequence is recognized through analysis of drilled cores (Bueno et al., 2007) that is not part of the evolution of the basin but may still hold important hydrocarbon potential. The prerift megasequence is represented by Paleozoic and Mesozoic lithologies belonging to the intracratonic Parana Basin (known in onshore Uruguay as Norte Basin) that were deposited in a syneclise stage before the genesis of the Pelotas Basin. According to Dias et al. (1994), the Paleozoic megasequence was reached in the emerged portion of Pelotas Basin by a well (2-TO-1-RS) located near the city of Torres, in Rio Grande do Sul. The drilled megasequence is composed by three lithostratigraphic units deposited in a marine environment (the Rio Bonito, Palermo and Irati formations) during the lower Permian. The upper Paleozoic portion is represented by two units (the Teresina and Rio do Rasto formations) that were deposited in a fluviallacustrine-tidal environment, whereas the prerift Mesozoic sequence is composed of Upper Jurassic aeolian-fluvial sandstones of the Botucatú Formation and the Lower Cretaceous flood basalts of the Serra Geral Formation (Milani et al., 1994). In relation to this megasequence, the organic-rich black shale of the Irati Formation represents a potential source rock for the study area. However, if this formation is present in the Uruguayan segment of Pelotas Ba$\sin$, due to the distance to the mentioned well (approximately $600 \mathrm{~km}$ ), lateral facies changes must be taken into consideration.

The synrift megasequence fills in half-graben structures in the proximal part of the basin. The few drilled wells in this region encountered Barremian-Aptian age basalts of the Imbituba Formation (Lobo, 2007) and conglomerates of the Cassino Formation (Bueno et al., 2007). Distally, this megasequence is represented by seaward dipping reflectors (SDRs; Fontana, 1987, 1996). The postrift megasequence represents the marine sedimentation of the basin and was divided in three main sequences by Bueno et al. (2007): shelfal, transgressive and regressive. According to these authors, the shelfal sequence is represented by Albian carbonate and siliciclastic deposits of the Porto Belo Formation that were deposited in a shallow, mixed-shelf environment. The transgressive sequence ranges from Albian to Oligocene in age and is comprised of thick layers of shales of the Atlântida and Imbé formations. The regressive sequence is formed by sandstones and siltstones of the Neogene Cidreira Formation (Bueno et al., 2007).

\section{Results and discussion}

The methodology used in this study was defined by Hubbard et al. (1985), and is based on the concepts of sequence stratigraphy, consisting of four main processes:

(i) Identification of sequence boundaries.

(ii) Interpretation of internal attributes (system tracts, maximum flooding surfaces). Following Catuneanu (2006), we employ the four systems tract model consisting of: Lowstand System Tract (LST), Transgressive System Tract (TST), Highstand System Tract (HST), and Falling Stage System Tract (FSST).

(iii) Development of a geological model: generation of maps showing the elements of the petroleum systems (source rocks, reservoirs, seals, etc.).

(iv) Structural analysis: identification of structures and migration paths for hydrocarbons.

\subsection{Seismostratigraphic analysis}

As a result of the application of the methodology explained above, we identify three main megasequences that constitute the Pelotas Basin infill: prerift, synrift and postrift (Fig. 2), each of which are discussed separately below. This is in agreement with earlier works concerning the Brazilian portion of the basin (Fontana, 1987; Bueno et al., 2007). Two second order unconformities that allow the individualization of these megasequences were interpreted from seismic. The first one constitutes an erosional surface with subaerial exposure that marks an angular unconformity separating the Paleozoic to Mesozoic age prerift from the other megasequences. This second order unconformity represents an important time gap that increases towards the continent, since sediments from synrift (lower Cretaceous) and postrift (Cretaceous to Miocene) megasequences are deposited in onlap above the erosional surface. The top synrift surface also represents a second order angular unconformity that separates the SDRs and the volcano-sedimentary infill of the half-grabens from the postrift sediments deposited from lower Aptian to Maastrichtian in onlap above the unconformity. Moreover, we recognized ten depositional sequences for the postrift megasequence (see below; Fig. 2). Both the ages of the depositional sequences and the mentioned time gap of the second order unconformities were established using the biostratigraphic data from the Gaviotin X-1 well.

\subsubsection{Prerift}

The prerift megasequence extends through the proximal region of the basin overlying the Polonio high, a basement high that marks its depositional limit. To identify this prerift megasequence, we used the same criteria that Morales (2013) used to map this package in offshore Uruguay: tilted, subparallel reflectors with high acoustic impedance contrast and without growth of the section related to faults. These criteria allowed us to differentiate the prerift deposits from both those of the synrift and basement lithologies. Although the seismic resolution does not allow recognition of system tracts for this package, it was possible for us to identify truncations of the reflectors on the top of the megasequence (Fig. 3), thus allowing us to confirm that the upper limit represents an important angular unconformity.

The isochore map of the prerift shows the development of this megasequence over the Polonio high that thins out towards the 


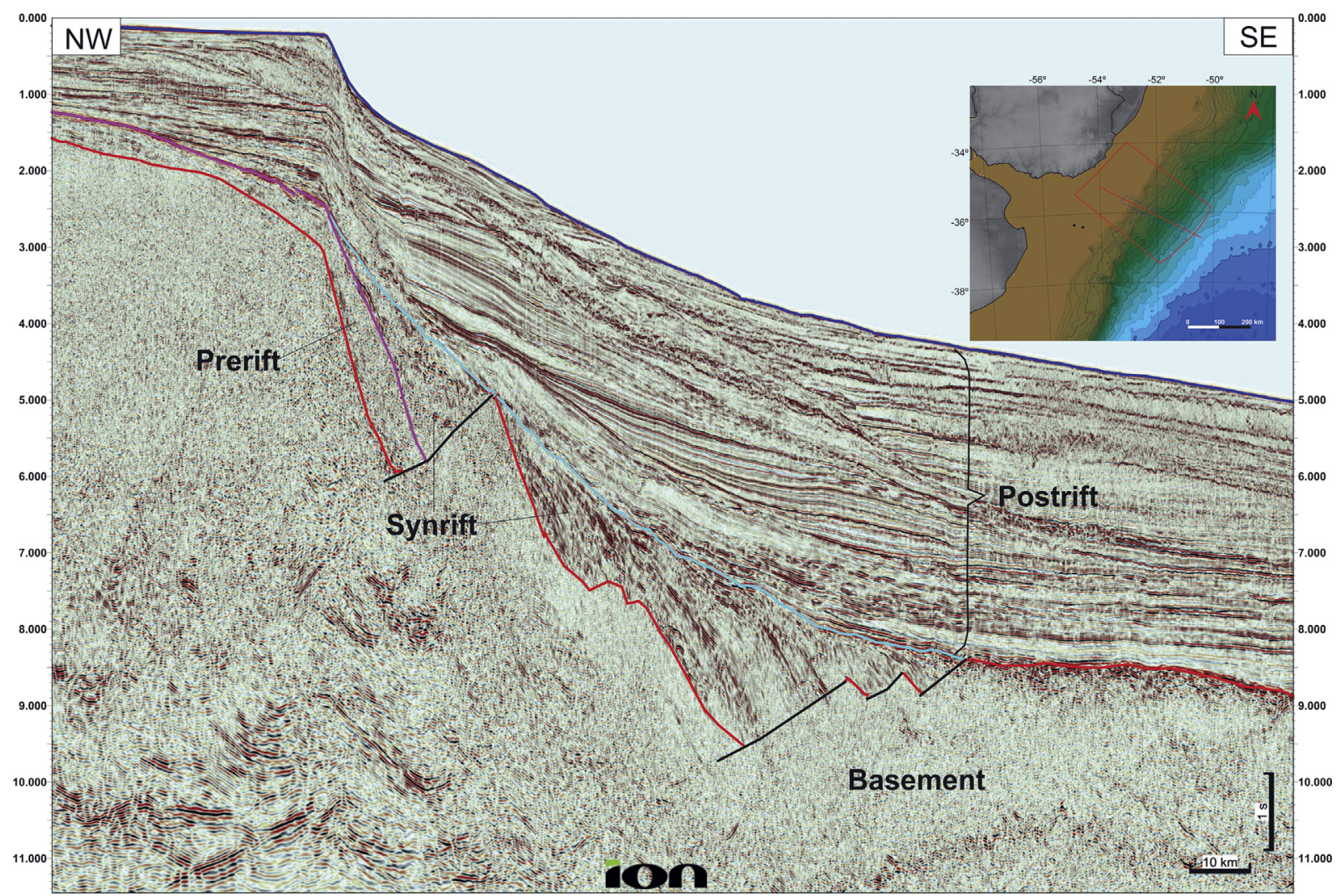

Fig. 2. 2D dip seismic section in time (TWT) of Pelotas Basin with interpreted megasequences. Vertical scale in seconds.

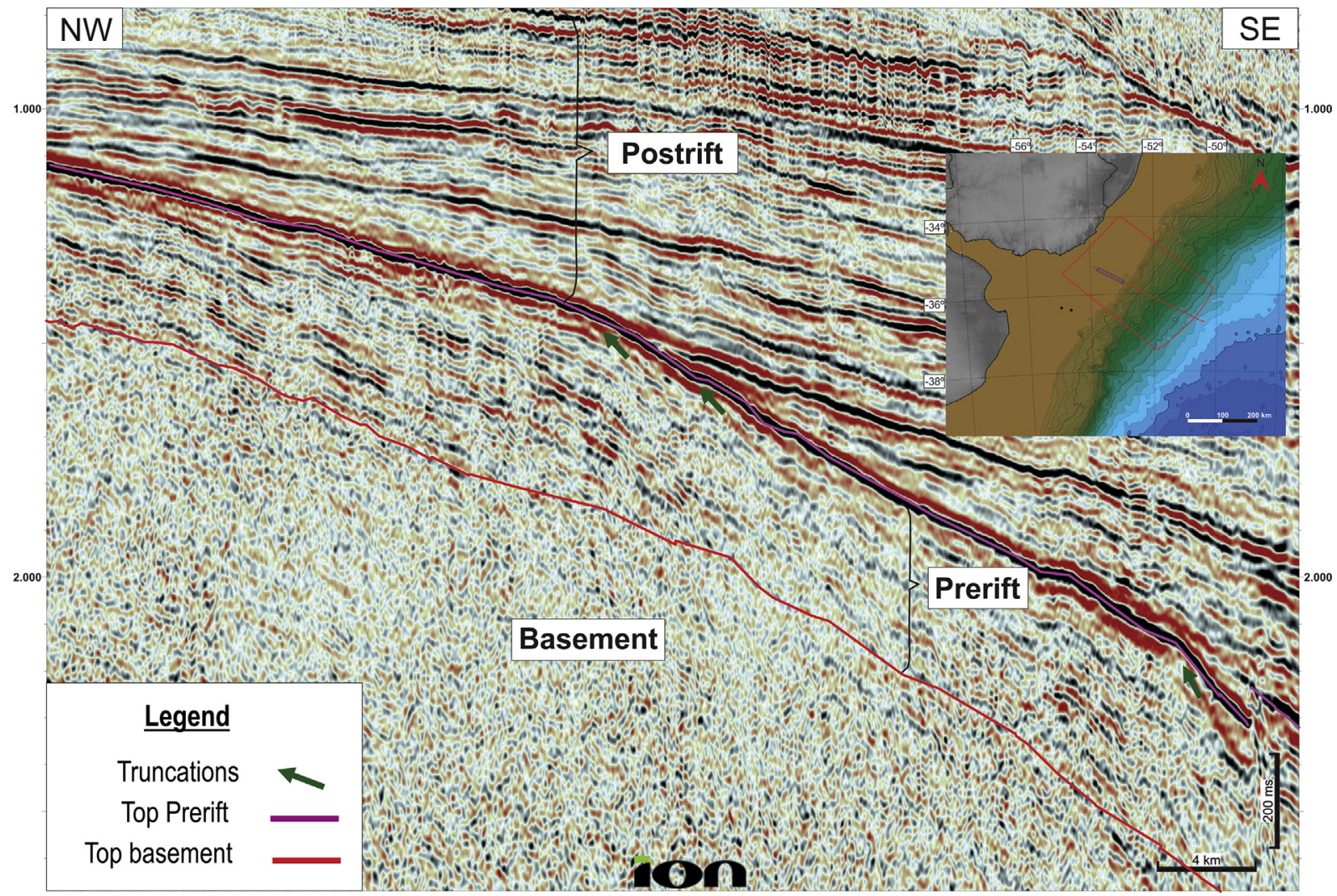

Fig. 3. Seismic character of the Prerift megasequence showing truncation of reflectors at the top of the megasequence. Vertical scale in seconds (TWT) 
continent (Fig. 4). In the southern edge of the Polonio high the Prerift megasequence is tilted and preserved beneath the halfgrabens of the synrift section (Fig. 2).

Importantly, black shales of the Irati Formation, a potential source rock for the area of study, were among the prerift lithologies drilled in the onshore portion of Pelotas Basin although, as mentioned before, the well that encountered these facies (2-TO-1RS) is located at $600 \mathrm{~km}$ from the study area (Fig. 1). On the other hand, the Gaviotin x-1 well located in shallow waters of Punta del Este Basin, approximately at $100 \mathrm{~km}$ of the study area, drilled a prerift section constituted by lower Permian sandstones of Tres Islas Formation and upper Permian siltstones and sandstones of Yaguari and Buena Vista formations (Ucha et al., 2004). These sandstones represent potential reservoirs for the Paleozoic section of Pelotas Basin in the area of study. According to França et al. (1995), the Yaguari and Buena Vista formations, belonging to Uruguay's Norte Basin, are correlatable in Brazil's Parana Basin with Teresina and Rio do Rasto formations respectively, which are stratigraphically above the Irati Formation. Likewise, the Tres Islas Formation of Uruguay's Norte Basin is correlatable in Brazil's Parana Basin with the Rio Bonito Formation, which is stratigraphically below the Irati Formation. Thus, even though the presence of a Paleozoic prerift megasequence is interpreted from seismic in the area of study, to predict the infill of this section it must be taking into consideration not only lateral facies changes but also the preservation and erosion of some units.

\subsubsection{Synrift}

The synrift sucession (developed over continental crust) is associated with the volcano-sedimentary infill of half-grabens in the proximal basin area, and seaward dipping reflectors (SDRs) in the central and distal basin areas. In the cases of half-grabens and SDRs it is possible to notice how the synrift sequence becomes thicker against the faults, evidencing the syndepositional nature of the faults. A Barremian-Aptian age is attributed to this megasequence (Bueno et al., 2007). In a restricted area of the central part of the basin where the half-grabens and SDRs overlap, it is possible to observe that the proximal part of the SDRs wedge is deposited above the half-grabens infill, suggesting that the SDRs are slightly younger. This is in agreement with Stica et al. (2014) that affirm that beside the south to north propagation of the rift phase in Pelotas Basin, there is a concomitant polyphase rifting process propagating from west to east (basinward) towards the future oceanic spreading. The development of the half-grabens occurs in the central-west sector of the area, in relation to the NE-SW trending antithetic normal faults generated in the lower Cretaceous during the fragmentation of the Gondwana supercontinent.

In some cases, the reflectors related to the half-graben infill show high amplitudes and high dip angles, presumably the result of a volcanic component in its lithological composition. Parallel and continuous reflectors that can be related with lacustrine deposits, however, were also identified (Fig. 5). According to Bueno et al. (2007) the few wells that drilled the synrift half-grabens in the Brazilian side of Pelotas Basin allowed to recognize two phases, the first one represented by basalts of the Imbituba Formation and the second one constituted by siliciclastics facies of the Cassino Formation (conglomerates, diamictites and siltstones). These authors interpreted the units of the second phase as alluvial fans that progradates into lacustrine depocenters. It is important to notice that lacustrine facies have not been encountered in these wells probably due to their proximal position related to the half-grabens.

As shown in the isochore map for the half-grabens (Fig. 6), two depocenters separated by a basement high elongated in a NE-SW trend are identifiable in the west side of the area.

The SDRs package developed in the north-central part of the study area and represent the thickest and most widespread unit within the synrift megasequence. The SDRs features wedges of arched high amplitude reflectors, which dip seaward (Fig. 7). As with the half-grabens, the SDRs are controlled by antithetic, NNE-

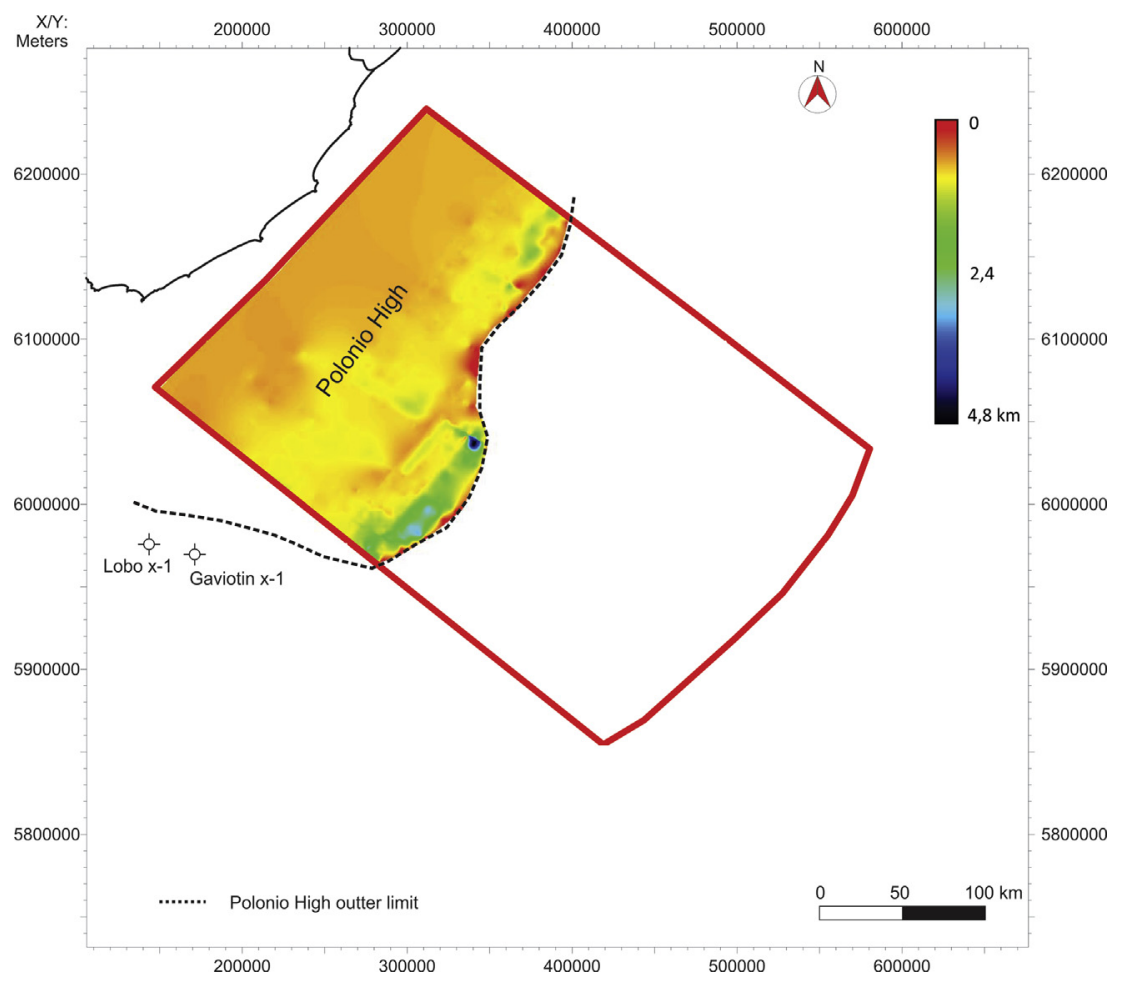

Fig. 4. Isochore map of the prerift megasequence in km showing the outter limit of the Polonio High. 


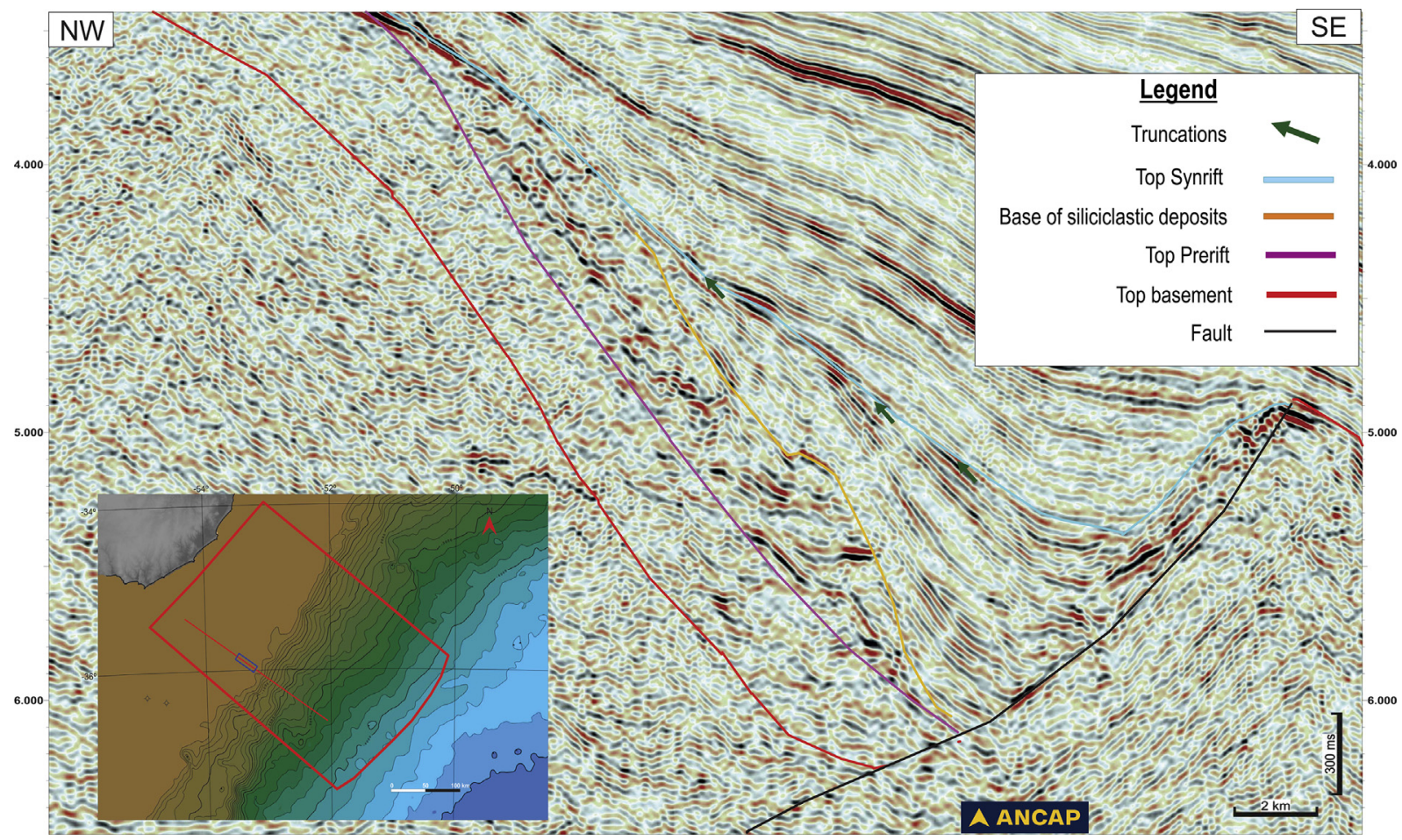

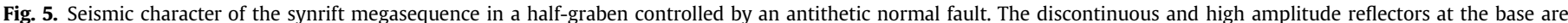

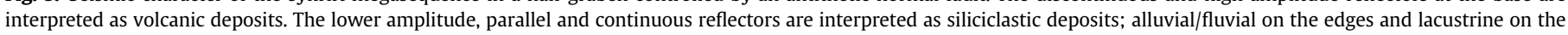
center of the half-graben. Vertical scale in seconds (TWT).

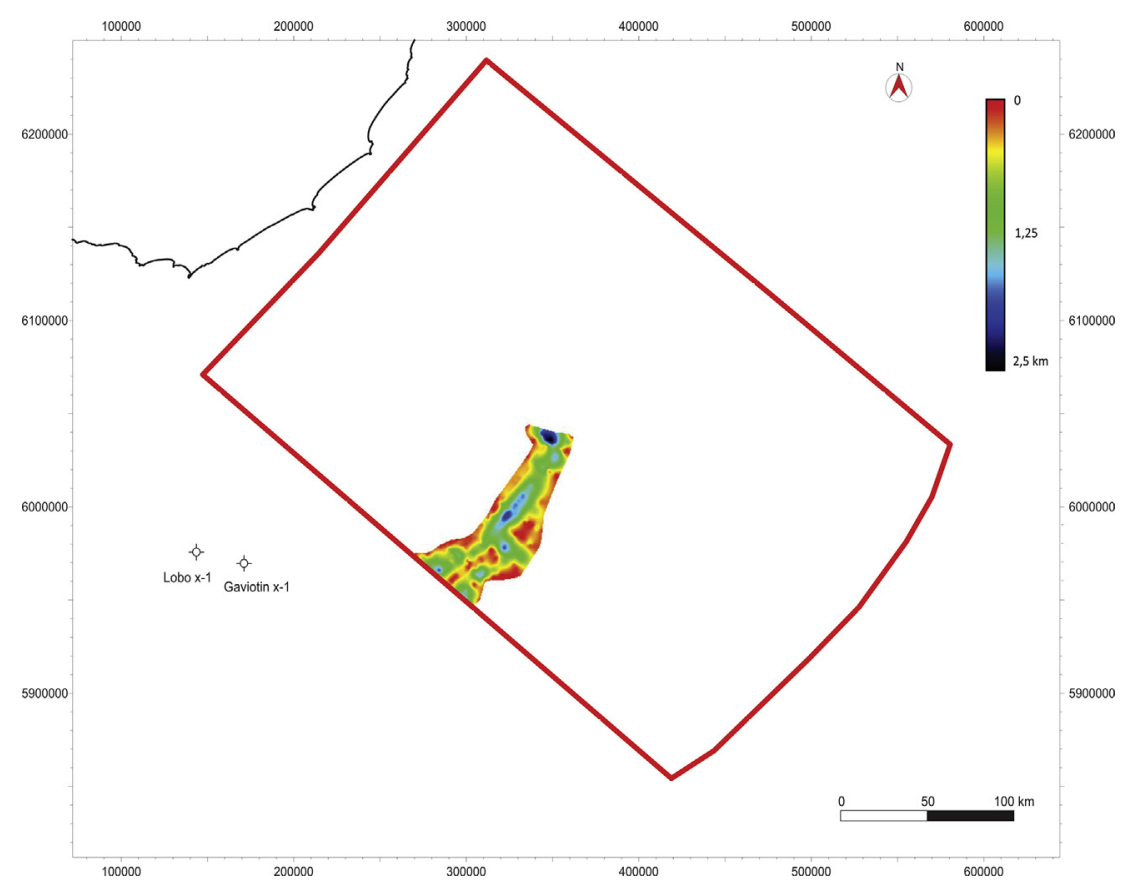

Fig. 6. Isochore map of the synrift section associated with half-grabens in $\mathrm{km}$.

SSW trending normal faults.

According to several authors (Franke et al., 2007; Soto et al., 2011; Stica et al., 2014) this package is composed of successive volcanic flows deposited in a continental environment with an inferred (non-negligible) sedimentary component (see below).

As visualized in the isochore map of SDRs (Fig. 8), the thickest section corresponds to the north-central part of the study area.

The possible presence of lacustrine source rock in the half-grabens highlights the importance of the synrift megasequence to the potential petroleum systems of Pelotas Basin. The Orange Basin (Offshore South Africa) is an example of hydrocarbons generation in synrift half-grabens with a similar tectonic environment to the 


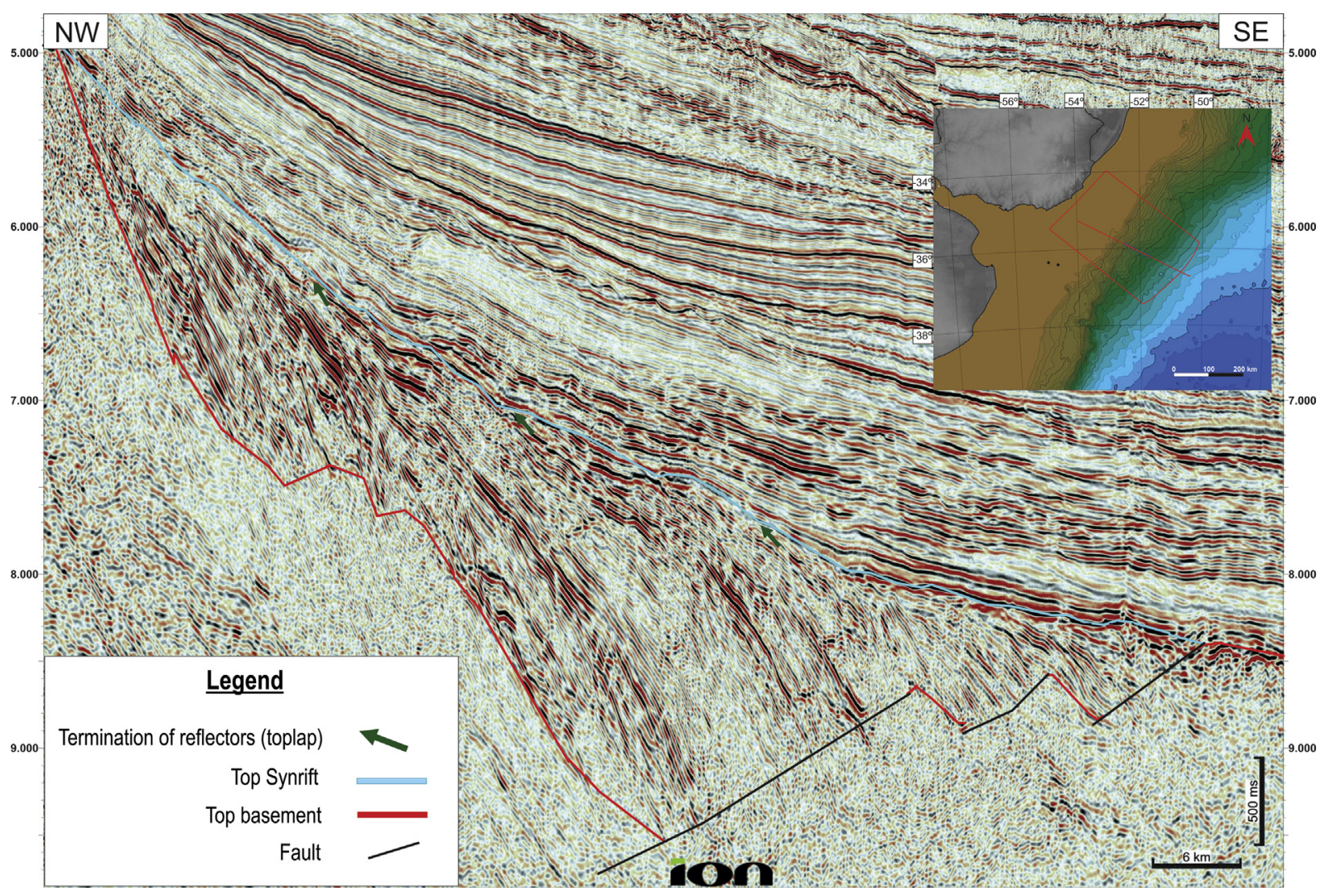

Fig. 7. Seismic character of the synrift associated with the SDRs in dip seismic section. Vertical scale in seconds (TWT).

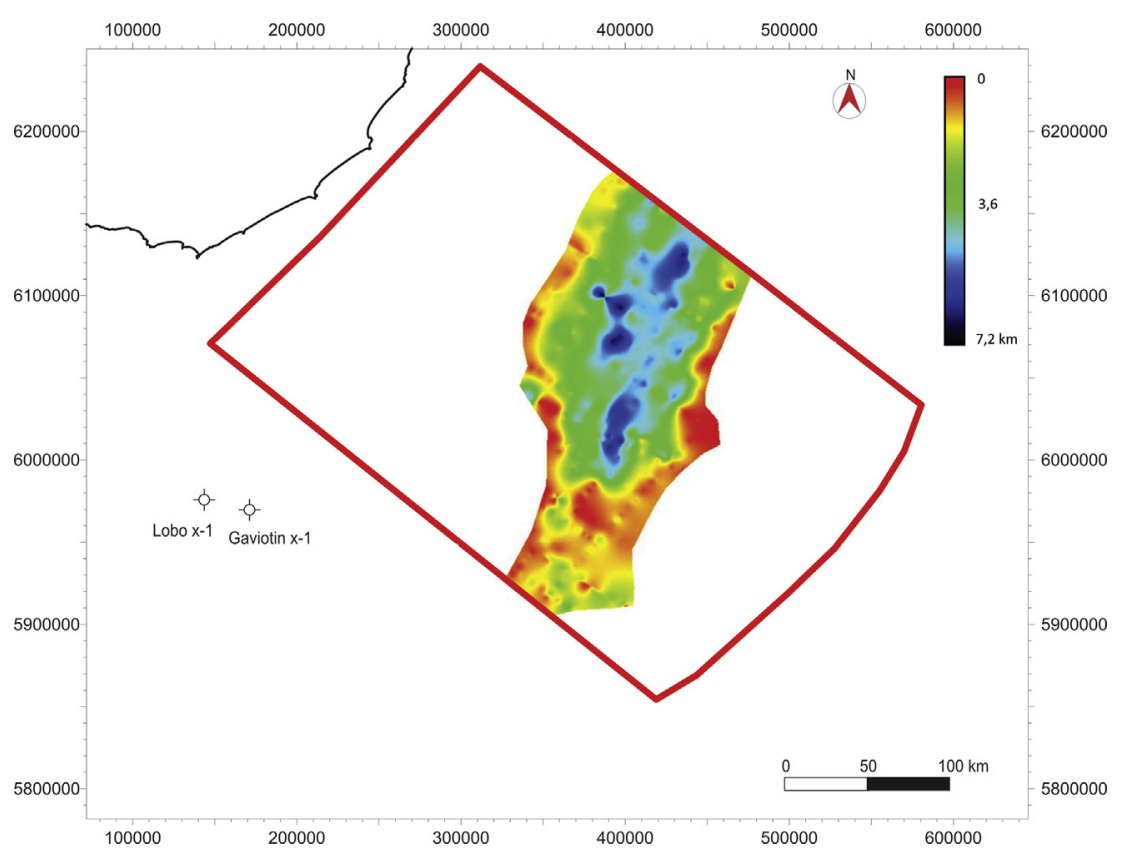

Fig. 8. Isochore map of the SDRs in $\mathrm{km}$.

Pelotas Basin. The AJ1 well drilled in the center position of a halfgraben in Orange Basin, encountered a proven source interval that comprises Hauterivian oil prone lacustrine black shales with a total organic content (TOC) greater than 10\% (Paton et al., 2007). The alluvial deposits of the Cassino Formation that may appear interbedded with the shales constitute potential reservoirs. On the other hand, the SDRs package may represent potential reservoirs associated with aeolian intertraps interbedded with volcanic rocks, as demonstrated by the similar lithology of the Kudu Gas field in offshore Namibia (Bray and Lawrence, 1999). 


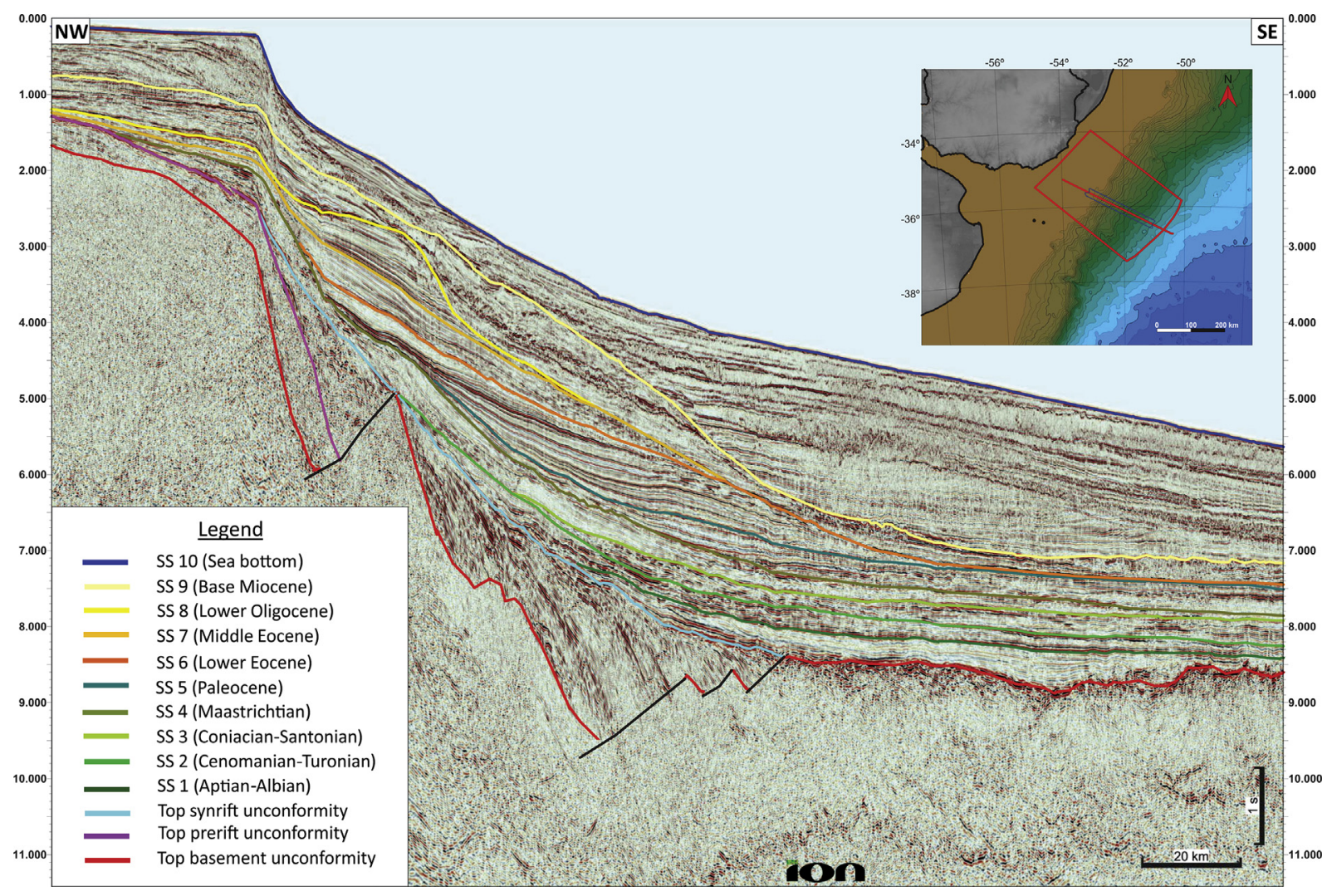

Fig. 9. 2D dip seismic section of the Pelotas Basin showing the interpreted depositional sequences. Vertical scale in seconds (TWT).

Table 1

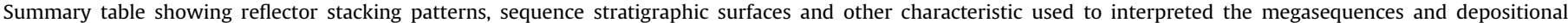
sequences.

\begin{tabular}{|c|c|c|c|c|c|c|}
\hline Megasequence & $\begin{array}{l}\text { Dep. } \\
\text { Seq. }\end{array}$ & $\begin{array}{l}\text { Base limit } \\
\text { surface }\end{array}$ & $\begin{array}{l}\text { Top } \\
\text { limit } \\
\text { surface }\end{array}$ & Characteristics, stacking patterns & $\begin{array}{l}\text { System } \\
\text { tracts }\end{array}$ & Inferred age \\
\hline Prerift & - & $\begin{array}{l}\text { Top } \\
\text { Basement }\end{array}$ & $\begin{array}{l}\text { Top } \\
\text { Prerift }\end{array}$ & $\begin{array}{l}\text { Tilted subparallel reflectors, high acoustic impedance, no growth of the section related to } \\
\text { faults }\end{array}$ & - & $\begin{array}{l}\text { Lower Permian-Lower } \\
\text { Cretaceous } \\
\text { (Hauterivian) }\end{array}$ \\
\hline Synrift & - & $\begin{array}{l}\text { Top } \\
\text { Basement, } \\
\text { Top Prerift }\end{array}$ & $\begin{array}{l}\text { Top } \\
\text { Synrift }\end{array}$ & $\begin{array}{l}\text { High amplitude and high dip angle reflectors, parallel and continuous reflectors, seaward } \\
\text { dipping reflectors, growth of the section related to faults }\end{array}$ & - & Barremian-Aptian \\
\hline Postrift & 1 & $\begin{array}{l}\text { Top } \\
\text { Basement }\end{array}$ & SS1 & $\begin{array}{l}\text { Retrogradational pattern with onlap terminations, progradational pattern with downlap } \\
\text { terminations }\end{array}$ & $\begin{array}{l}\text { TST, } \\
\text { HST }\end{array}$ & Aptian-Albian \\
\hline Postrift & 2 & SS1 & SS2 & $\begin{array}{l}\text { Retrogradational pattern and onlap terminations, progradational pattern with downlap } \\
\text { terminations }\end{array}$ & $\begin{array}{l}\text { TST, } \\
\text { HST }\end{array}$ & Cenomanian-Turonian \\
\hline Postrift & 3 & SS2 & SS3 & Sigmoidal progradational pattern with downlap terminations & $\begin{array}{l}\text { TST- } \\
\text { HST }\end{array}$ & Conician-Santonian \\
\hline Postrift & 4 & SS3 & SS4 & $\begin{array}{l}\text { Prograding clinoforms with onlap and downlap terminations, prograding clinoforms } \\
\text { with offlap terminations }\end{array}$ & $\begin{array}{l}\text { HST, } \\
\text { FSST }\end{array}$ & $\begin{array}{l}\text { Caampanian- } \\
\text { Maastrichtian }\end{array}$ \\
\hline Postrift & 5 & SS4 & SS5 & $\begin{array}{l}\text { Reflectors with lobular shape and both side downlap termintations, retrogradational } \\
\text { pattern with onlap terminations, progradational pattern with downlap terminations }\end{array}$ & $\begin{array}{l}\text { LST, } \\
\text { TST, } \\
\text { HST }\end{array}$ & Paleocene \\
\hline Postrift & 6 & SS5 & SS6 & $\begin{array}{l}\text { Retrogradational pattern with onlap terminations, progradational pattern with downlap } \\
\text { terminations }\end{array}$ & $\begin{array}{l}\text { TST, } \\
\text { HST }\end{array}$ & Lower Eocene \\
\hline Postrift & 7 & SS6 & SS7 & Progradational pattern with downlap terminations & HST & Middle Eocene \\
\hline Postrift & 8 & SS7 & SS8 & Progradational pattern with downlap terminations & HST & $\begin{array}{l}\text { Upper Eocene-Lower } \\
\text { Oligocene }\end{array}$ \\
\hline Postrift & 9 & SS8 & SS9 & Progradational pattern with downlap terminations & HST & Upper Oligocene \\
\hline Postrift & 10 & SS9 & SS10 & $\begin{array}{l}\text { Reflectors with lobular shape with both side downlap terminations, retrogradational } \\
\text { pattern with onlap terminations, progradational pattern with downlap terminations }\end{array}$ & $\begin{array}{l}\text { LST, } \\
\text { TST, } \\
\text { HST }\end{array}$ & Miocene-Holocene \\
\hline
\end{tabular}

\subsubsection{Postrift}

We consider the postrift megasequence to have the greatest exploratory potential as it likely contains the most important and widespread source rocks (Aptian and Turonian) as well as high quality and abundant reservoirs (e.g. turbidites). Additionally, the postrift megasequence comprises several thick and widespread 


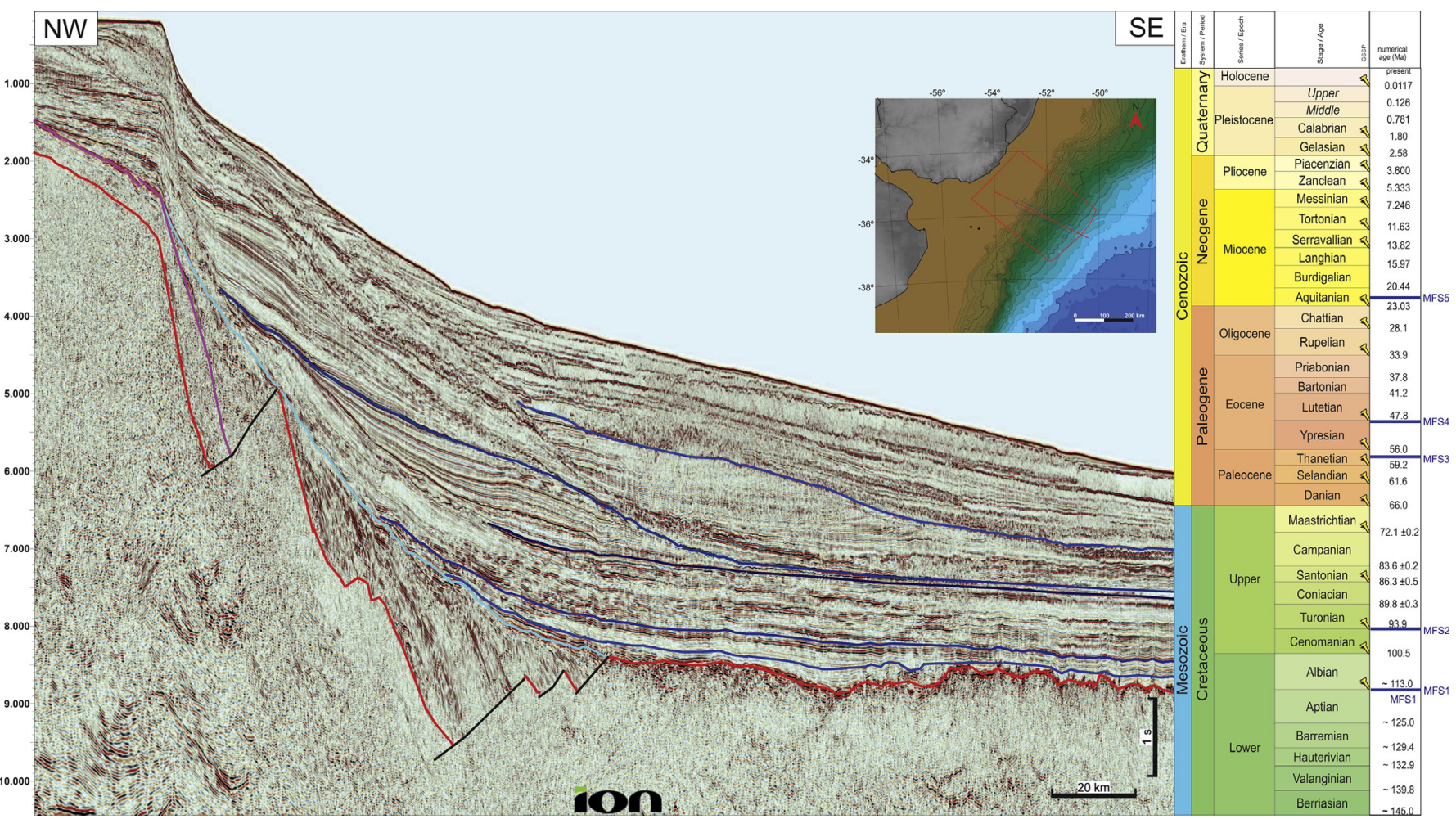

Fig. 10. 2D dip seismic section showing the distribution of the interpreted maximum flooding surfaces and their locations on the stratigraphic column. Vertical scale in seconds (TWT).

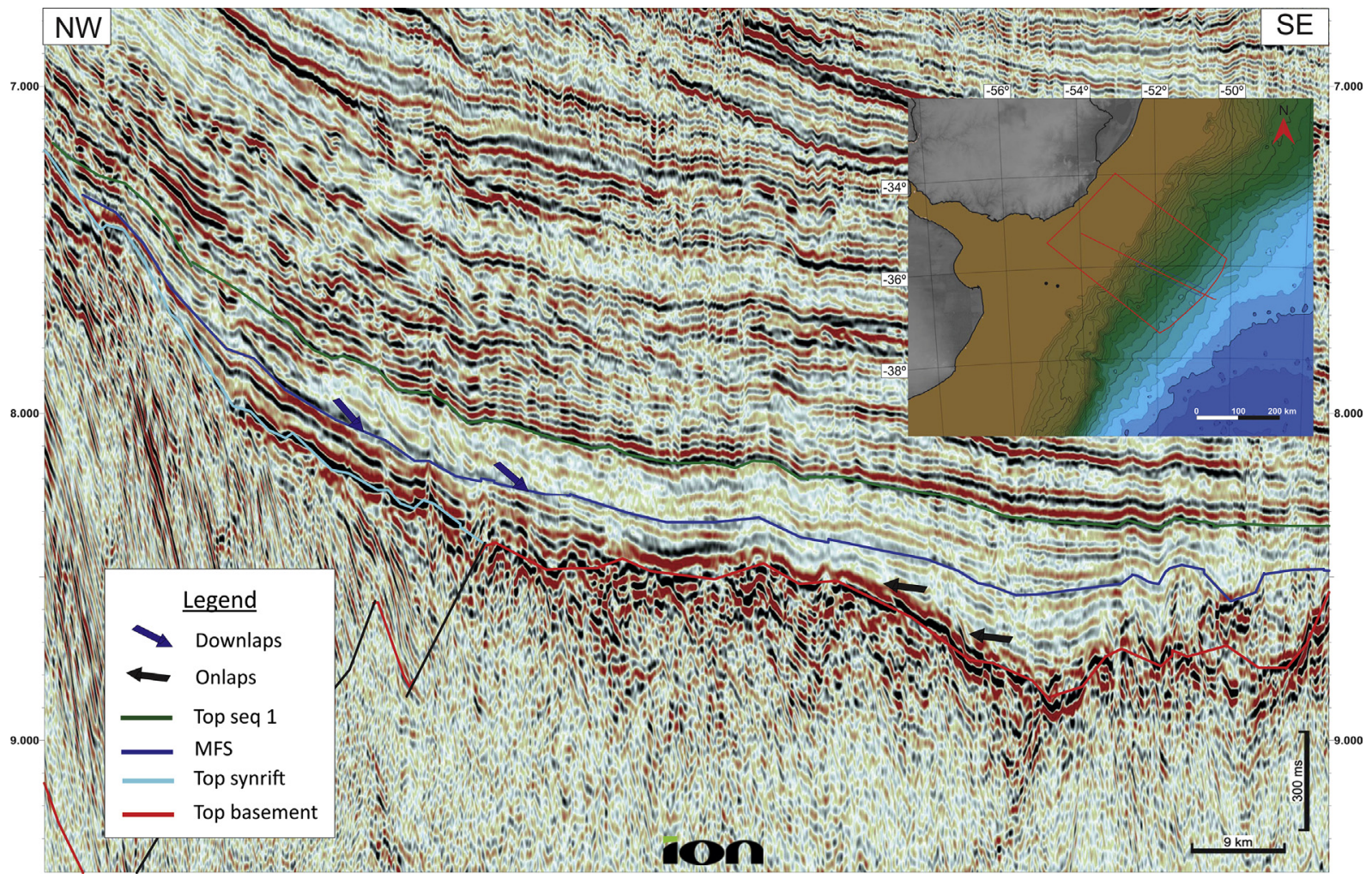

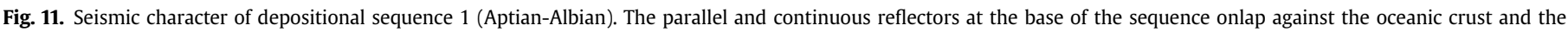
SDRs. In the proximal section we distinguish a set of reflectors downlapping over the maximum flooding surface. Vertical scale in seconds (TWT)

clay-rich levels that represent potential hydrocarbon seals. The deposition of the postrift megasequence is fundamentally controlled by sea level variations in a passive margin stage that continues to the present. 
Using the sequence stratigraphy methodology described in Section 2, ten stratigraphic surfaces (SS) have been used to define ten third-order depositional units with either retrogradational or progradational stacking patterns. The extension of each one of these stratigraphic surfaces is shown in a dip seismic section of the study area in Fig. 9.

These stratigraphic surfaces represent, in some cases, minor unconformities passing basinward to correlative conformities (SS3, SS5). In other cases, the surfaces appear to be actual sequence boundaries (SS1, SS2, SS5), limiting units that form a depositional sequence. Also, in other cases these surfaces may represent prominent unconformities, such as, SS4 and SS9, that are associated with significant descent of the sea level (maximum regressive surfaces) during the late Maastrichtian and late Oligocene, respectively. The characteristics of each depositional sequence are resumed in Table 1.

We interpret the system tracts that comprise each depositional sequence to identify potential elements of the speculative petroleum systems. The sequence stratigraphy analysis also allows us to identify five third order maximum flooding surfaces (MFS) in the postrift section (Fig. 10). Considering that the distal portion of these flooding surfaces represent deep marine areas with organicrich shales, the MFS reveal the distribution of the potential source rock in the study area. Due to the thick sedimentary pile overlying these marine shales, however, it is likely that the Cretaceous source rocks, and to a lesser extent the Paleocene source rocks, had reached enough maturity to generate and expel hydrocarbons. Below we describe in detail the depositional sequences that are directly related with the speculative petroleum systems proposed for the postrift (depositional sequences 1 to 5 ).

2.1.3.1. Depositional sequence 1 (Aptian-Albian). This depositional sequence develops in the distal region of the basin, directly overlying oceanic crust and pinches out against the SDRs. The sequence is bound at its base by basement rock and on the top by the sequence boundary SS1. The base is composed of a set of parallel

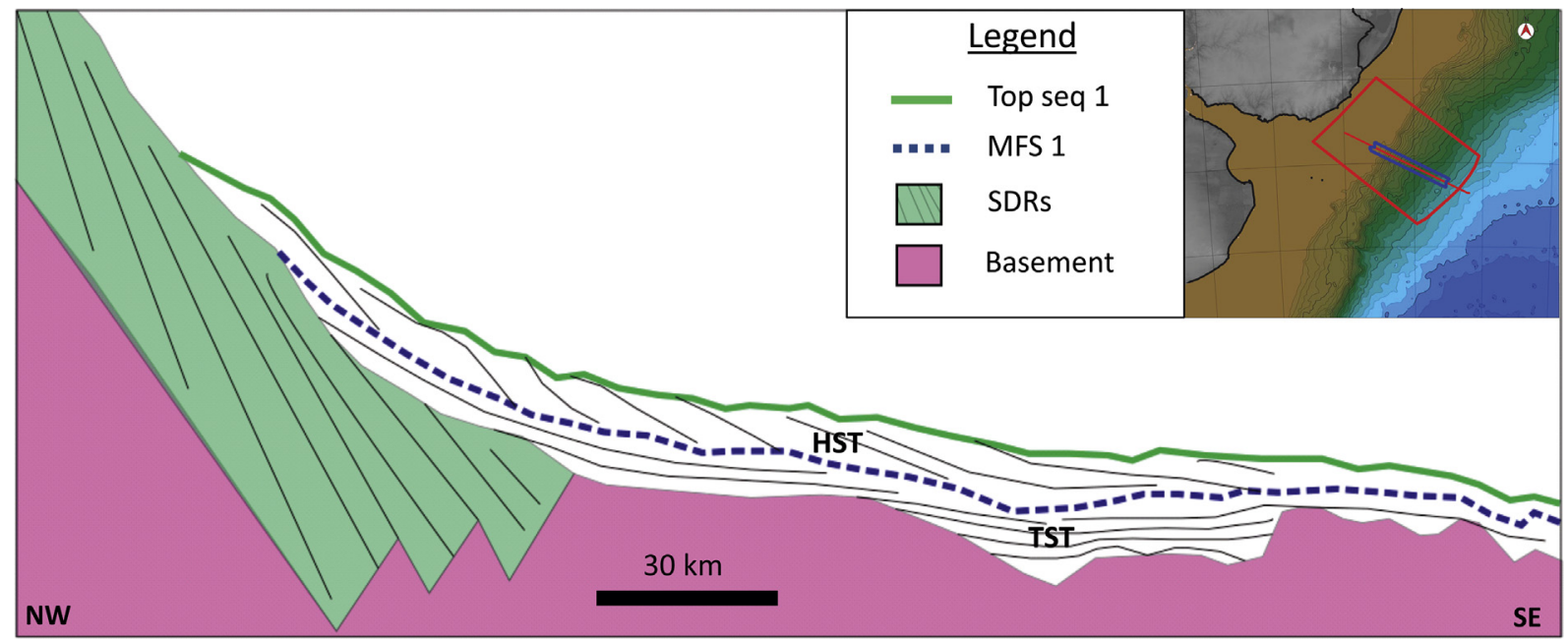

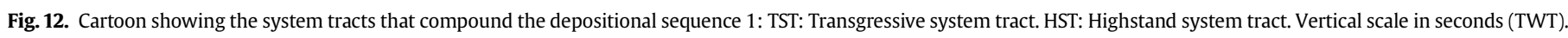

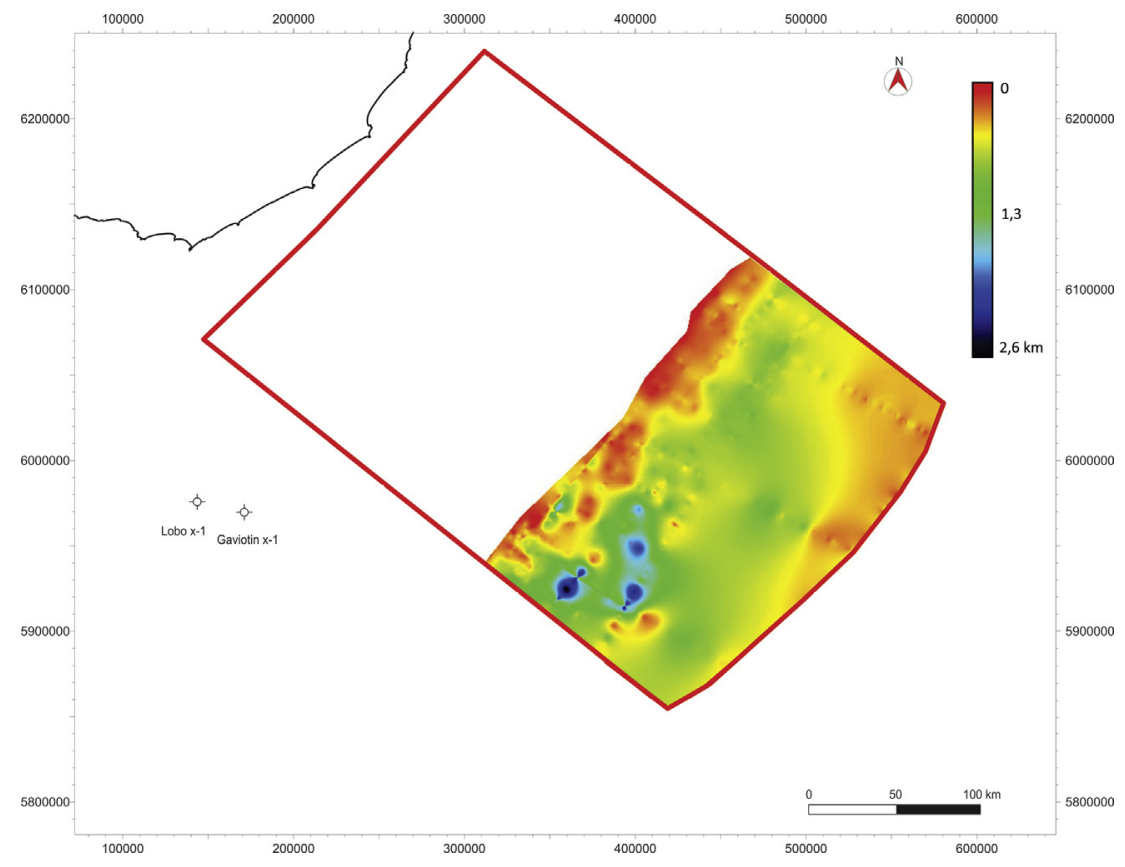

Fig. 13. Isochore map of the depositional sequence 1 (Aptian-Albian) in kms. 


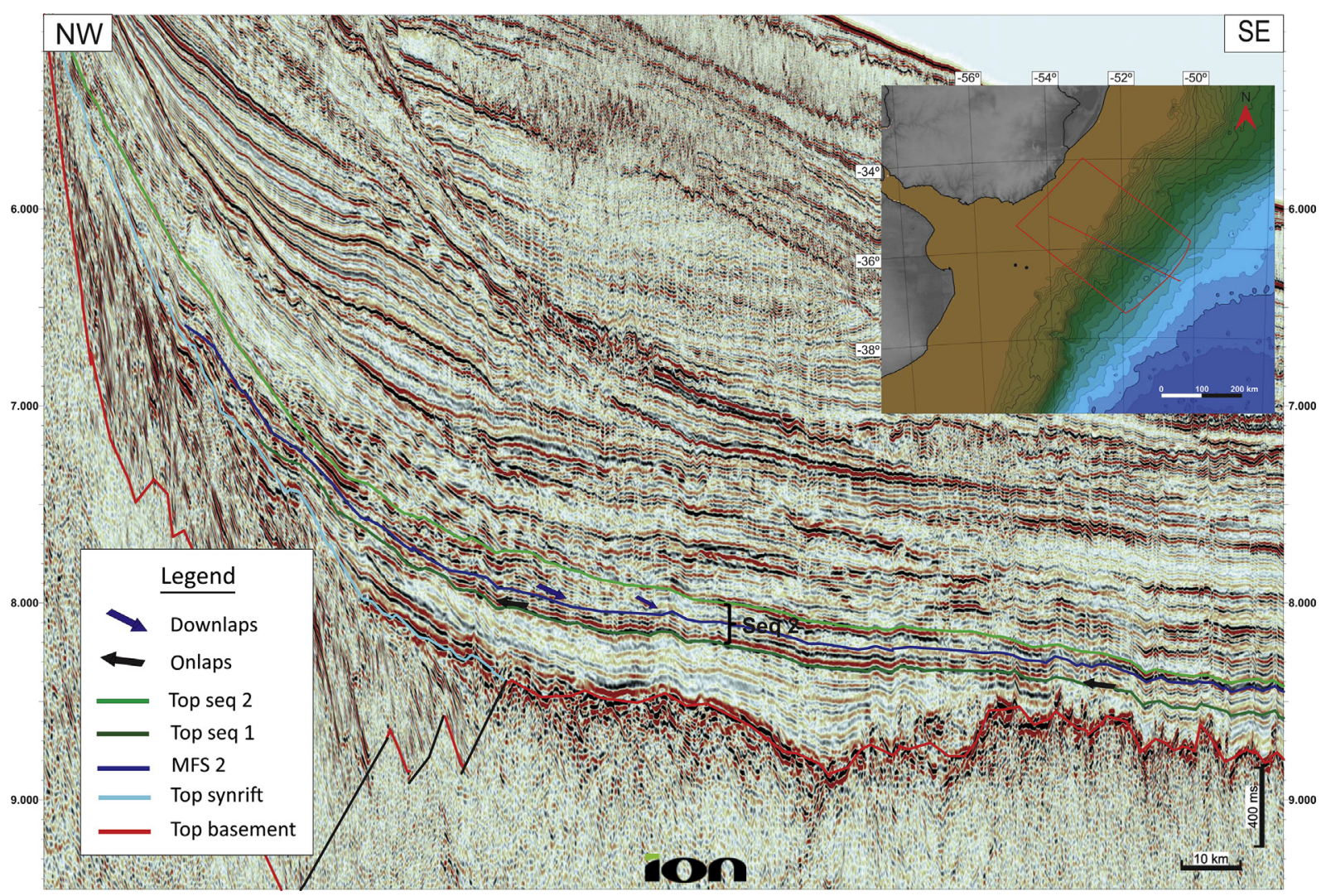

Fig. 14. Seismic character of depositional sequences 2 (Cenomanian-Turonian). Vertical scale in seconds (TWT).

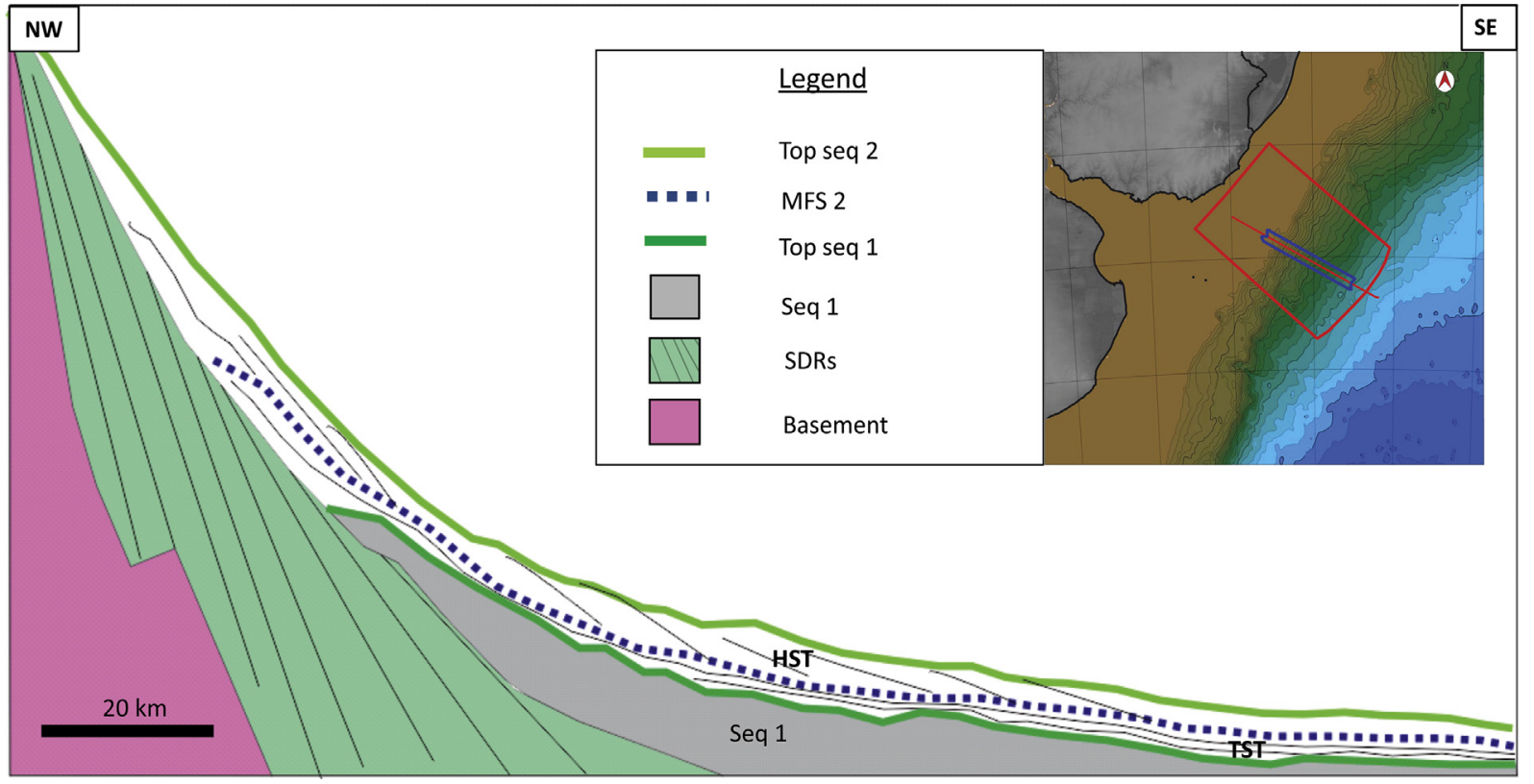

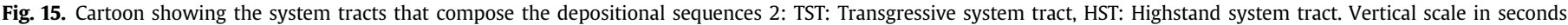
(TWT).

and continuous reflectors with a retrogradational stacking pattern that onlaps towards the continent against the oceanic crust and the SDRs (Fig. 11).

The reflectors at the base of the sequence with onlap terminations constitute a transgressive system tract (TST), which represent the first marine flooding of the basin and is comprised fundamentally of fine-grained marine sediments. A maximum flooding surface (MFS 1) developed on top of this set of reflectors. A set of reflectors with downlap terminations that show a sigmoidal and progradational pattern is recognized on top of this surface. These 
sets of reflectors are interpreted as a highstand system tract (HST; Fig. 12), in which fluvial, shelfal and shoreface deposits with potential as reservoirs possibly occur.

The depositional sequence 1 presents its thickest section preserved in the western part of the area (Fig. 13).

The depositional sequence 1 was deposited during Aptian-
Albian age, contemporary with the first Oceanic Anoxic Event of the Cretaceous (OAE1). Therefore, this TST is interpreted to contain organic-rich marine shales with source rock potential.

2.1.3.2. Depositional sequence 2 (Cenomanian-Turonian). The depositional sequence 2 develops in the distal and central region of

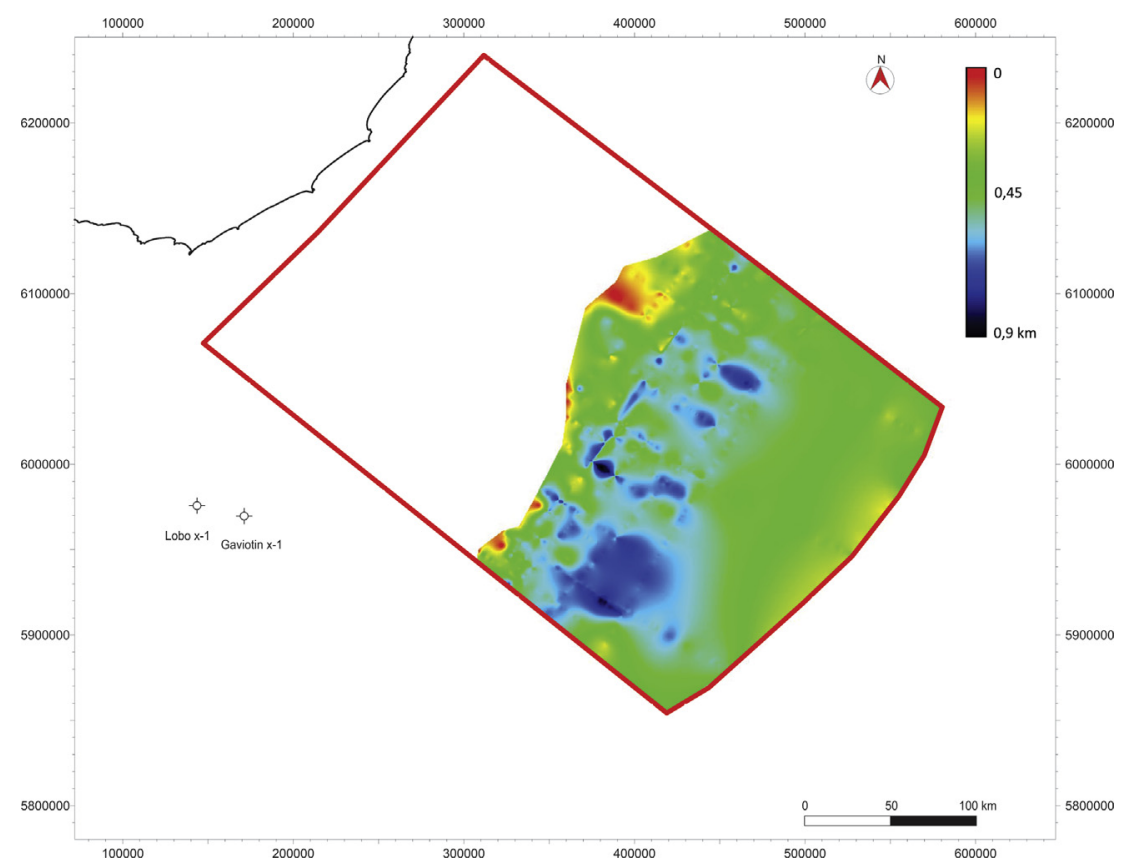

Fig. 16. Isochore map of the depositional sequence 2 in kms.

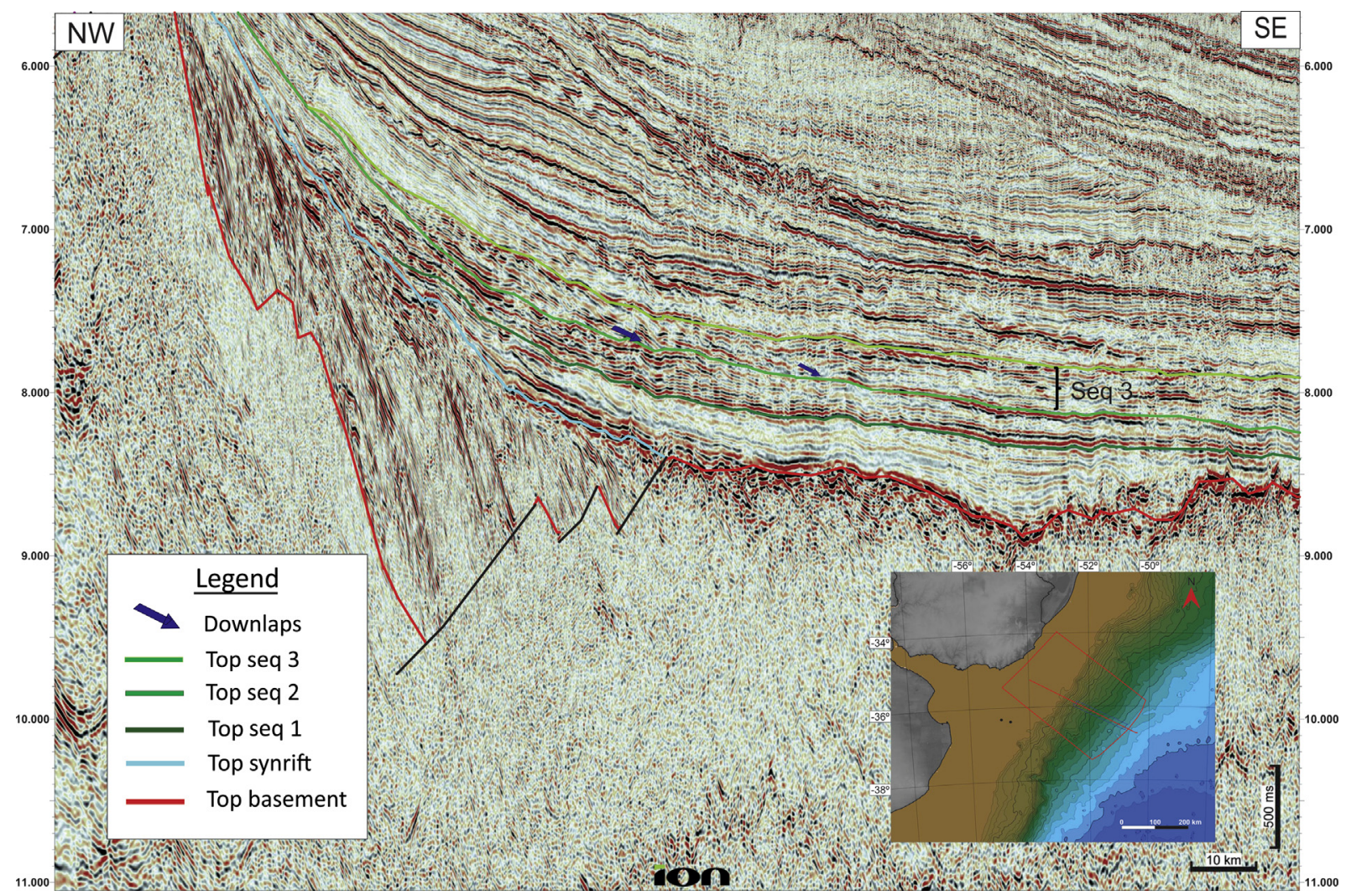

Fig. 17. Seismic character of depositional sequences 3 (Conician-Santonian). Vertical scale in seconds (TWT). 
the study area and thins out towards the continent against the SDRs. It is limited at the base by the stratigraphic surfaces SS1 and in the top by the stratigraphic surfaces SS2. Both of these surfaces appear to be actual sequence boundaries. At the base of the sequence is a set of parallel and continuous reflectors with a retrogradational stacking pattern that, in the distal region, lies concordantly against the transgressive system tract of the previous sequence. Moving towards the continent, this set of marine reflectors onlaps against, and then surpasses, the high stand system tract of the previous sequence (Fig. 14).

This set of reflectors is interpreted as a TST in which a second maximum flooding surface (MFS 2) is recognized at the top of the tract. In the proximal section of the sequence a different set of reflectors with a progradational stacking pattern (which advance towards the sea with downlap terminations), overlays the TST of this sequence. This set is interpreted as a HST (Fig. 15).

The depositional sequence 2 is interpreted as CenomanianTuronian in age. Organic-rich marine shales associated with the TST, deposited during the second oceanic anoxic event of the Cretaceous (OAE2) may be expected in this sequence. This sequence, thus, has important potential as a source rock. Additionally, the high-stand system tract could include lithologies, mainly sandstones, with reservoir potential, fundamentally in the proximal section. As with the depositional sequence 1 , the thickest section is located in the west side of the area (Fig. 16).

2.1.3.3. Depositional sequence 3 (Coniacian-Santonian). The depositional sequence 3 developed in the distal and central regions of the study area and thins out towards the continent against the previous sequence (Fig. 17). It is limited in the base by the sequence

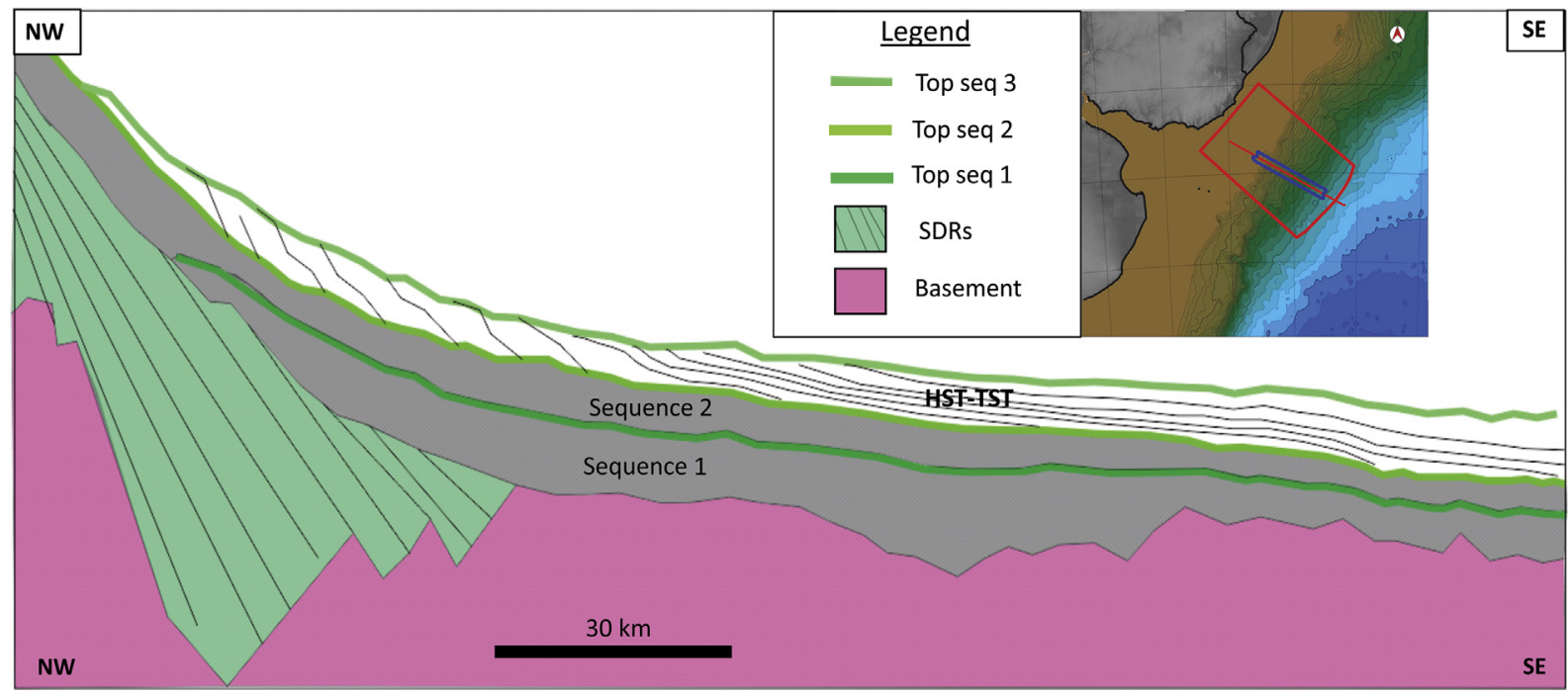

Fig. 18. Cartoon showing the system tract that composes the depositional sequences 3. TST: Transgressive system tract, HST: Highstand system tract.

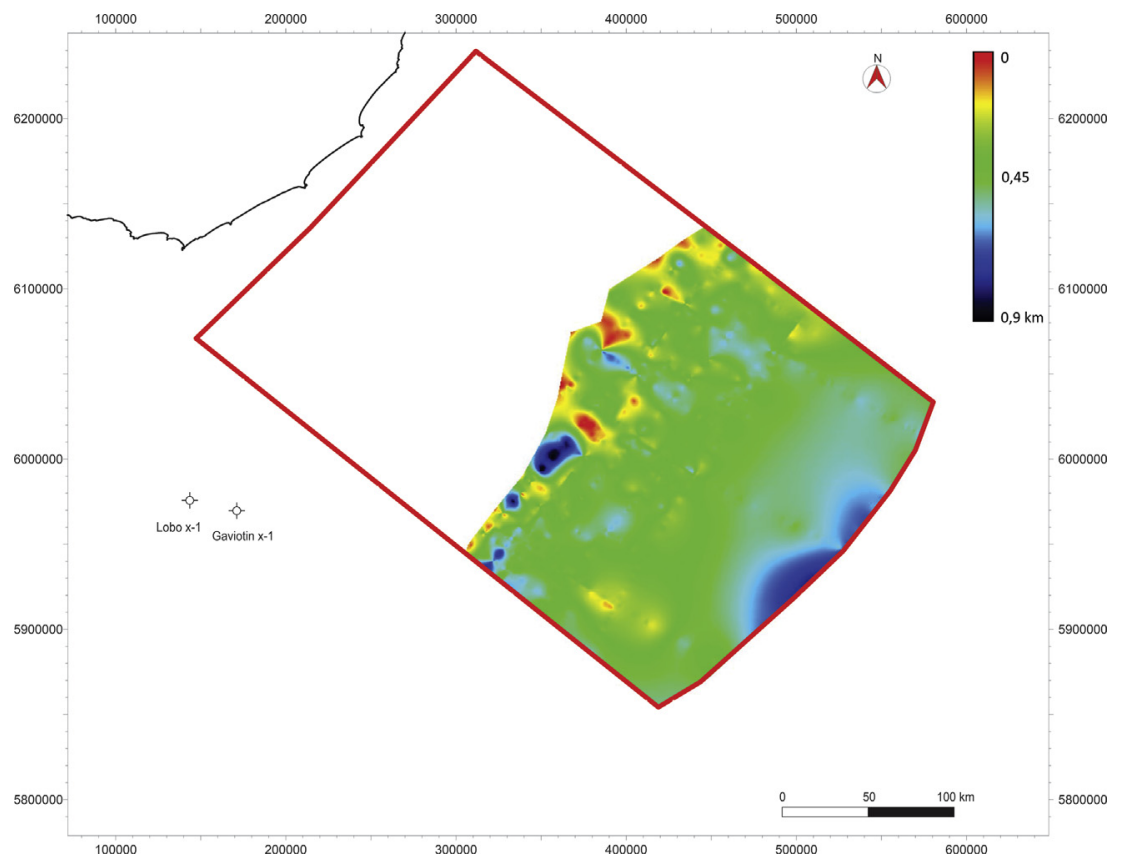

Fig. 19. Isochore map of the depositional sequence 3 in $\mathrm{kms}$. 


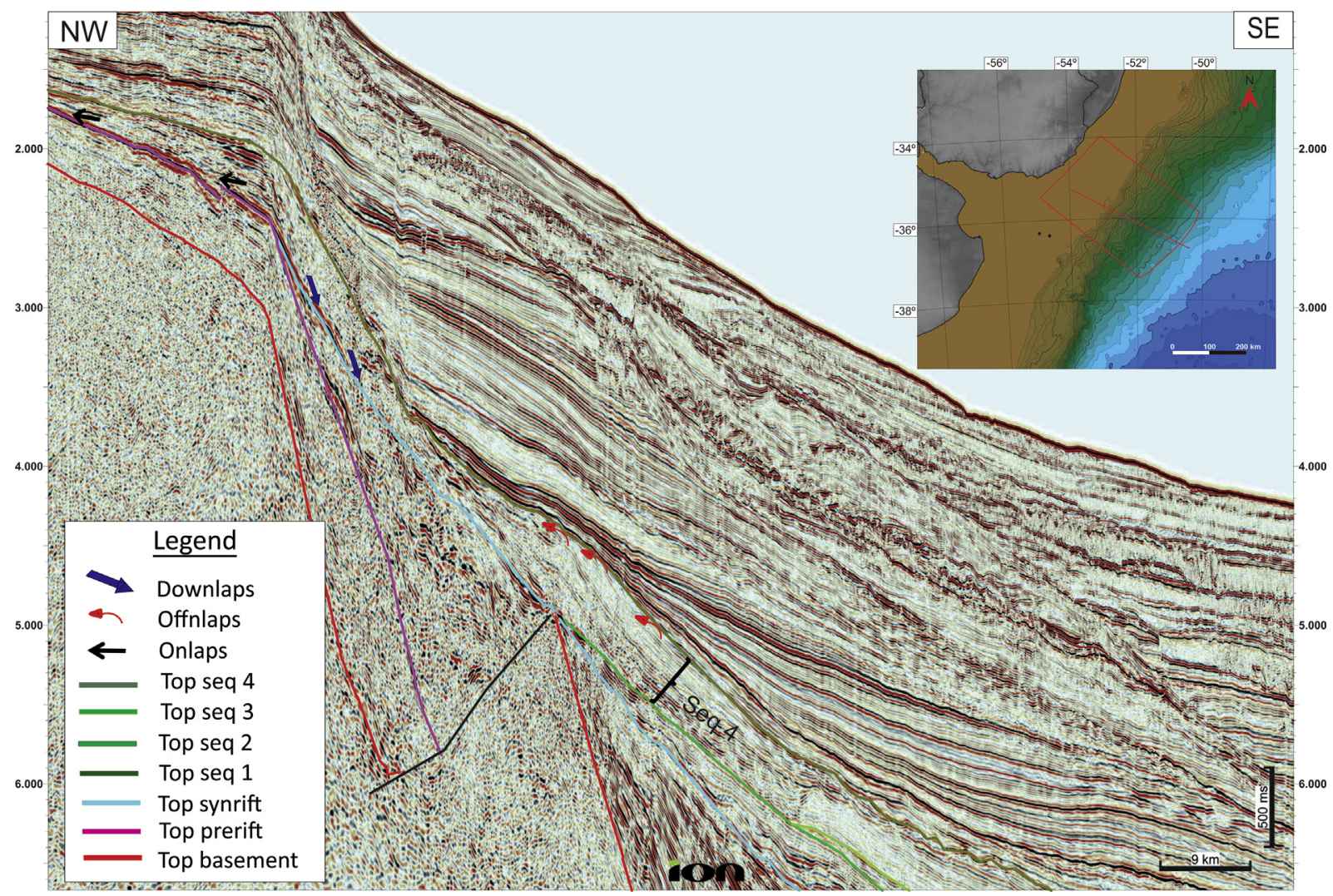

Fig. 20. Seismic character of depositional sequences 4 (Campanian-Maastrichtian). Vertical scale in seconds (TWT).

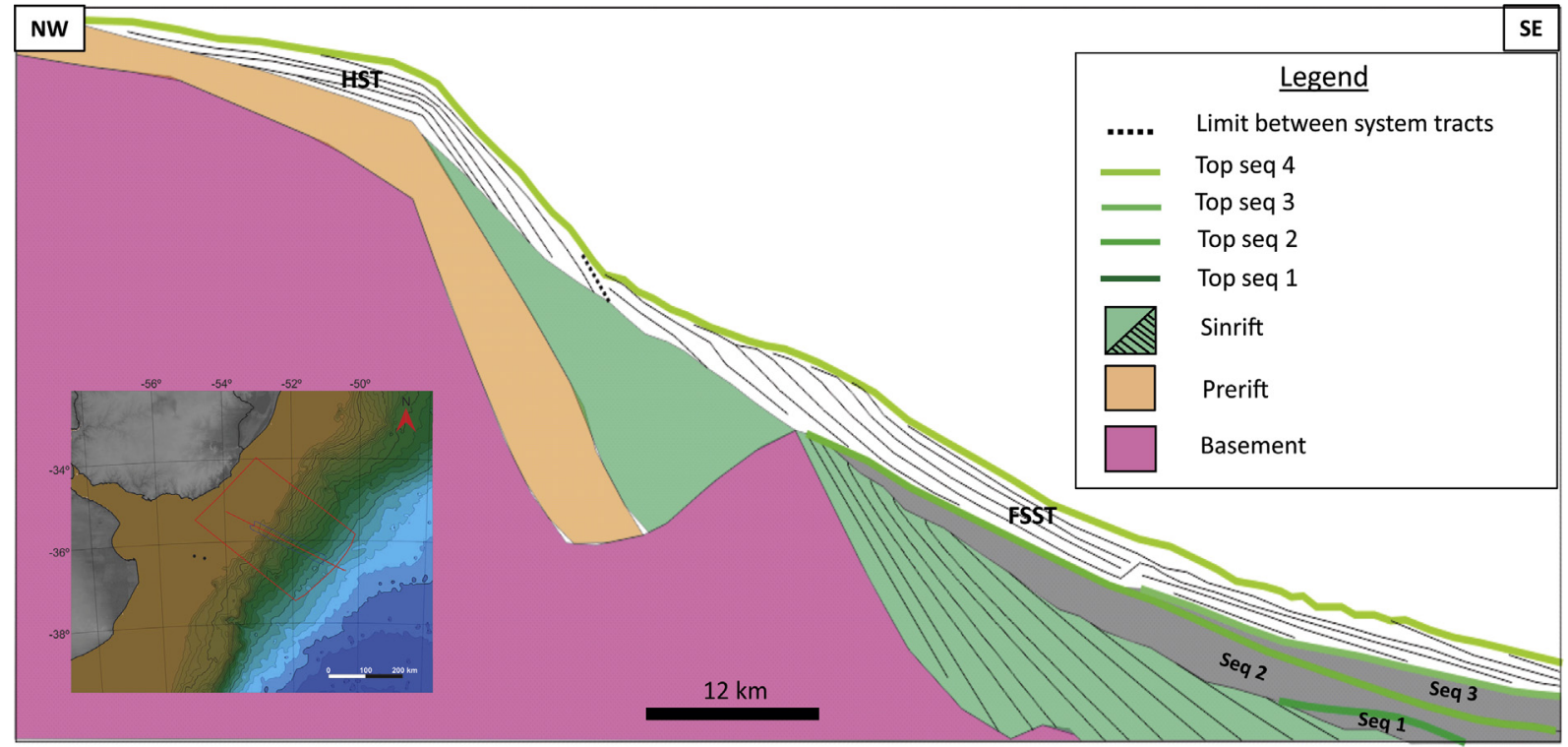

Fig. 21. Cartoon showing the system tracts that compose the depositional sequences 4, HST: Highstand system tract, FSST: Falling stage system tract.

boundary SS2 and in the top by the stratigraphic surfaces SS3 and presents a relatively constant thickness throughout (Fig. 19). It is represented mostly by a set of reflectors with a sigmoidal and progradant pattern that downlap directly over sequence 2 but unlike sequences 1 and 2, we do not recognize a clear retrogradant pattern at the base (Fig. 18). This sequence could be interpreted as a combination of TST-HST undifferentiated.

Due to its stratigraphic position, we attribute a Coniacian-
Santonian age for this sequence. The SS3 at the top of the sequence may represent an actual sequence boundary associated to a significant sea level fall registrated during the Santonian (Hardenbol et al., 1998). We suspect that this sequence is composed mostly of coarse siliciclastic deposits (e.g. sandstones), particularly in the proximal portion, and is associated with prograding sigmoidal figures that may represent high-quality reservoirs (i.e., porosities of $15-20 \%$ ). 


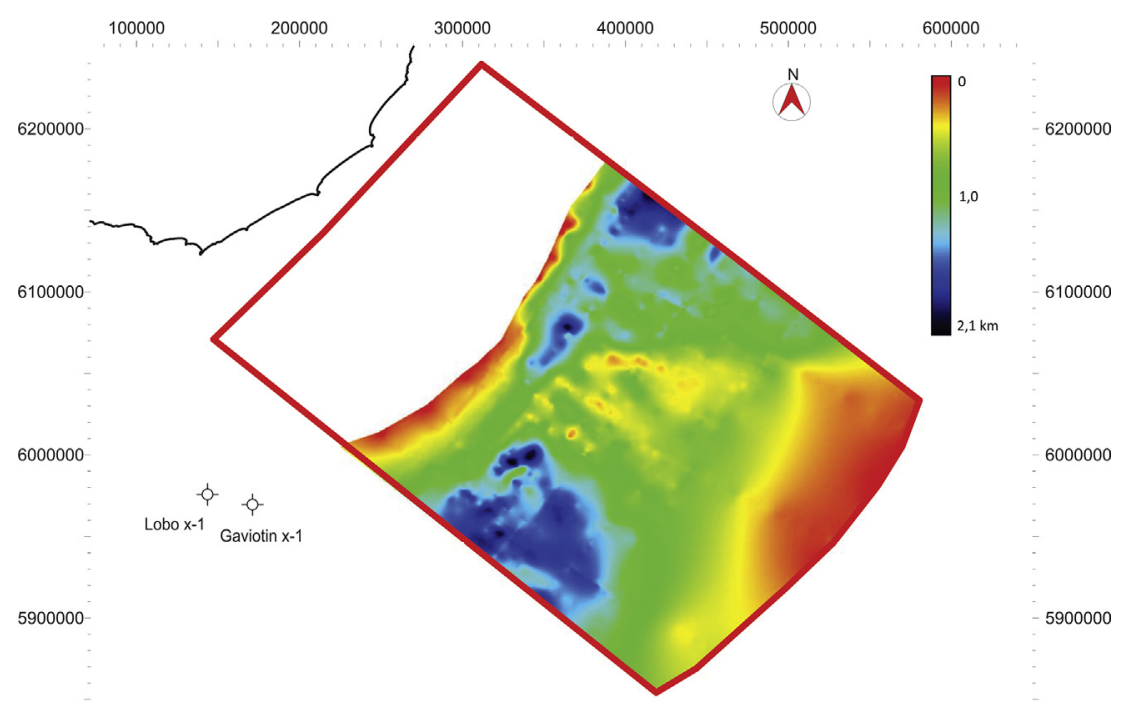

5800000

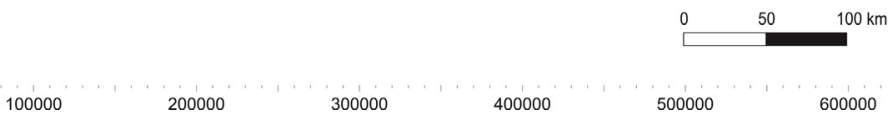

Fig. 22. Isochore map of the depositional sequence 4 in kms.

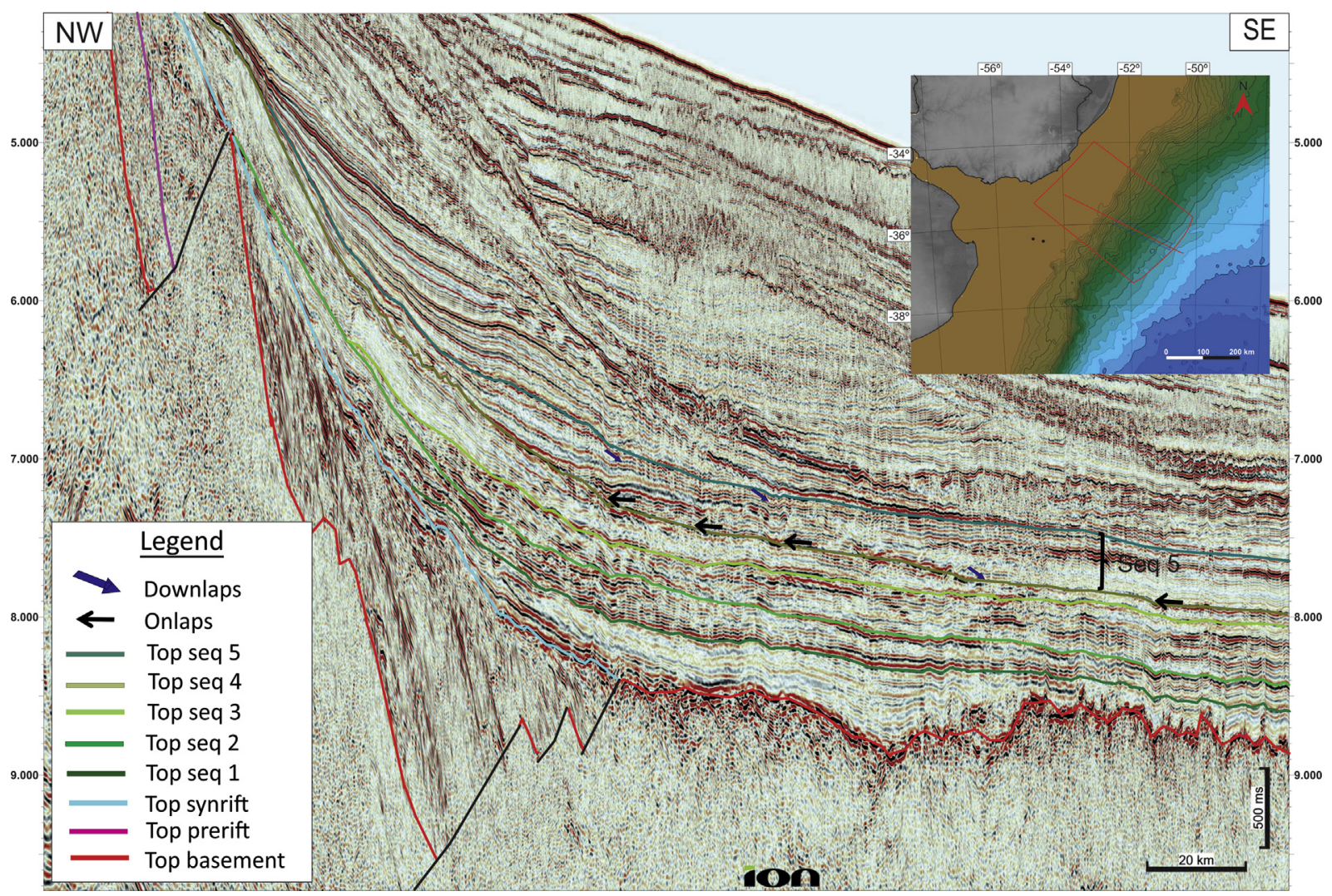

Fig. 23. Seismic character of the depositional sequence 5 (Lower Paleocene) showing typical terminations of the reflectors. Vertical scale in seconds (TWT).

2.1.3.4. Depositional sequence 4 (Campanian-Maastrichtian). Depositional sequence 4 is more widespread than the previous sequences. In the proximal portion, depositional sequence 4 lays directly over the prerift and synrift megasequences, whereas in the distal segment it overlies sequences 2 and 3. It is limited in the top by SS4, which represents a significant angular unconformity 


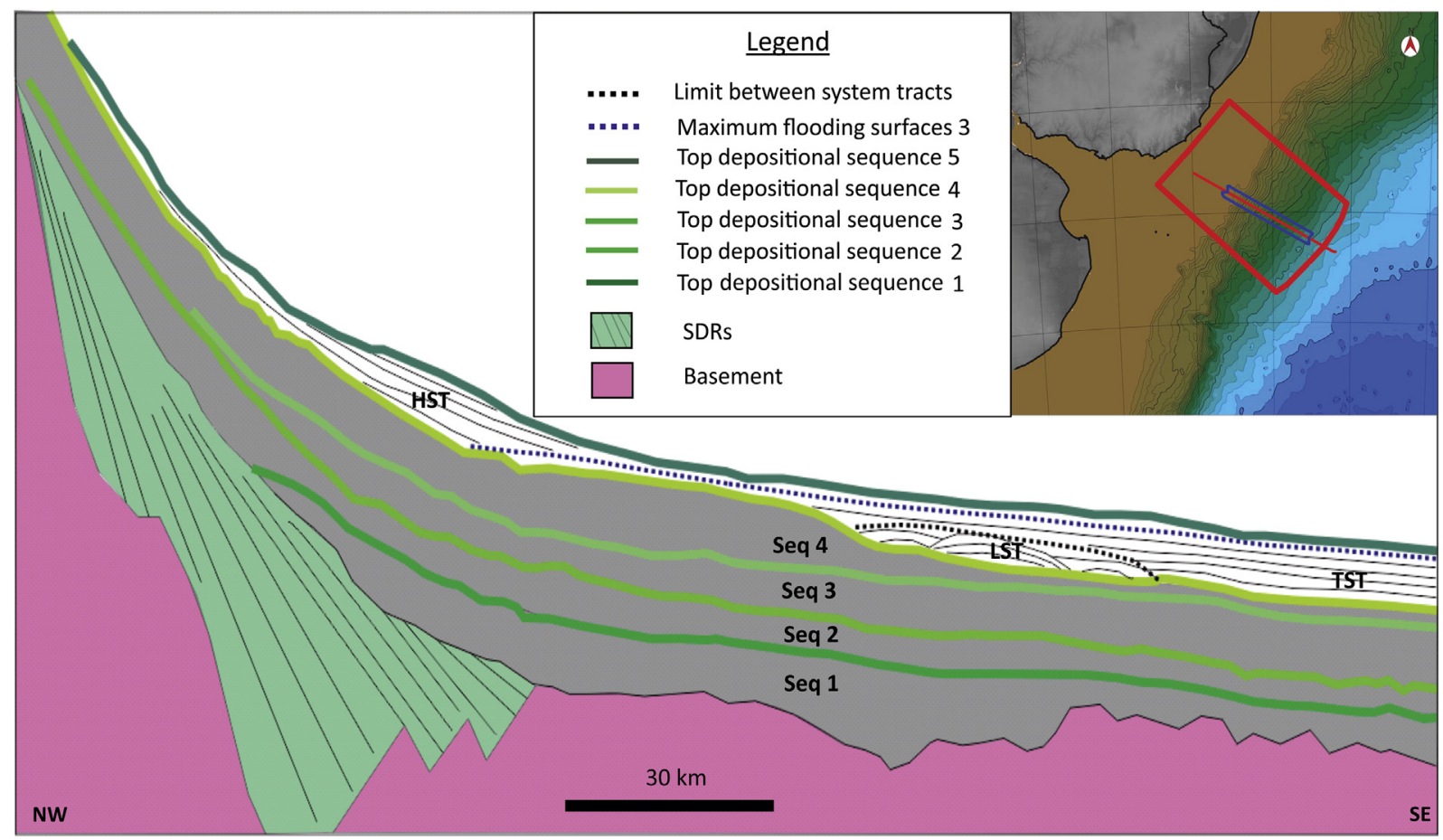

Fig. 24. Picture showing the system tracts that compose depositional sequence 5: LST: Lowstand system tract, TST: Transgressive system tract, HST: Highstand system tract.

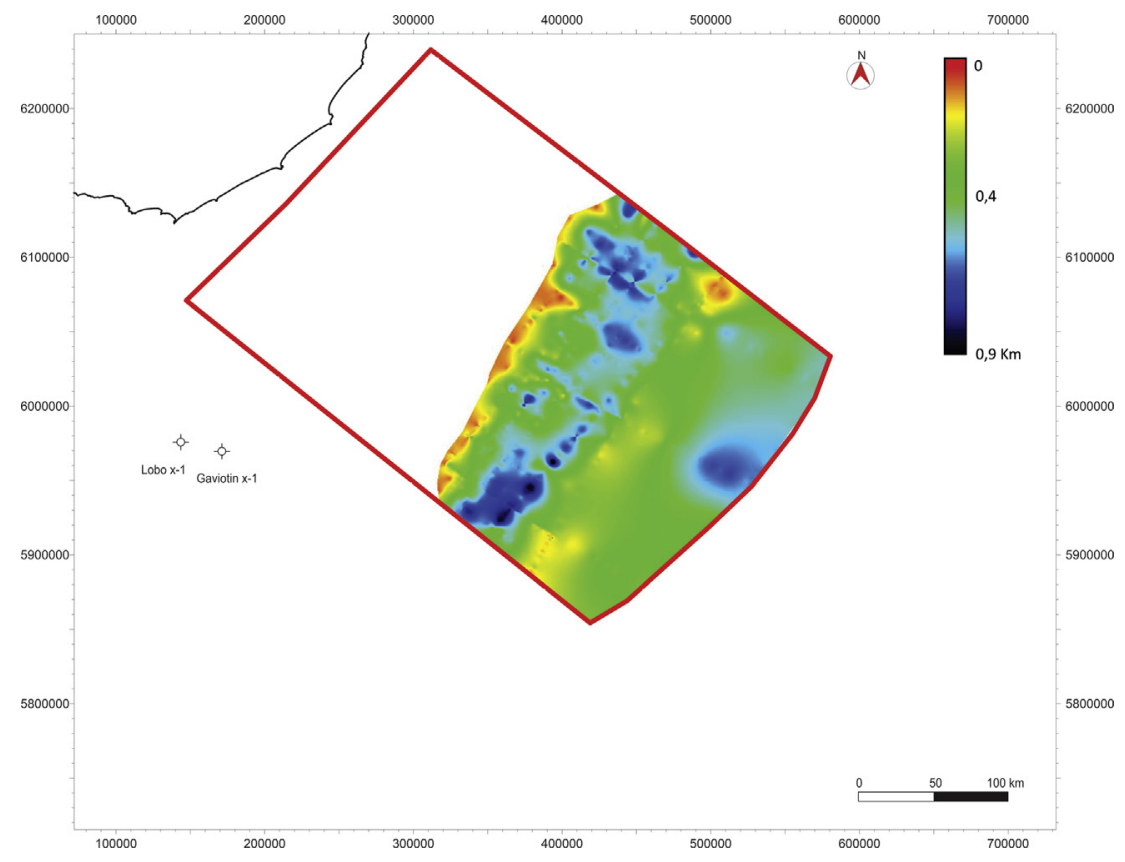

Fig. 25. Isochore map of depositional sequence 5 (Paleocene) in kms.

developed during the Maastrichtian. The first development of a paleoshelf and a paleoslope of the basin is also recognized here. In this area sequence 4 is represented by a set of clinoforms with a progradational pattern that onlaps towards the continent and downlaps towards the interior of the basin (Fig. 20), constituting a highstand system tract in which the shoreline progresses towards the sea (Fig. 21).

Moreover, in the distal section we observe a displacement of the shoreline that is probably associated with a relatively rapid fall of sea level. Current publications on global eustatic sea level curves
(Hardenbol et al., 1998; Snedden and Liu, 2010) support this interpretation, showing a marked descent on sea level during the Maastrichtian. Associated with this base-level fall we also recognize a set of prograding reflectors that present offlap terminations at their tops, in which every new reflector exposes a portion of the previous one (Fig. 21). The migration of the shoreline towards the basin together with the development of shallower clinoforms from proximal to distal areas, associated with the offlap terminations, are evidences of a forced regression. As a rapid fall of sea level generates erosion of the exposed shelf and formation of incised valleys, this set 


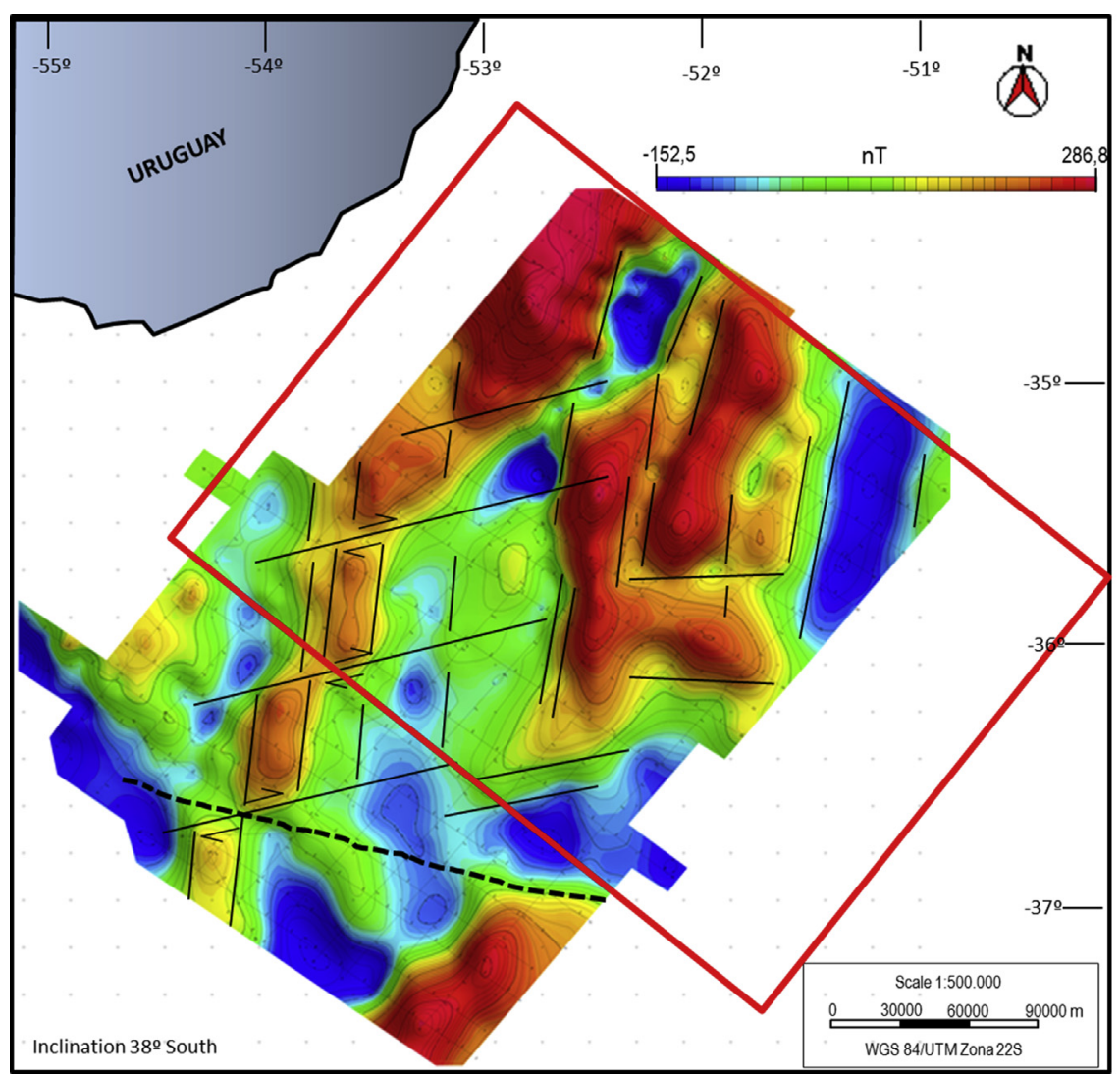

Fig. 26. Map of magnetic anomalies (Reduce to Pole) with structural interpretation showing the main lineaments (black solid lines) associated with faults.

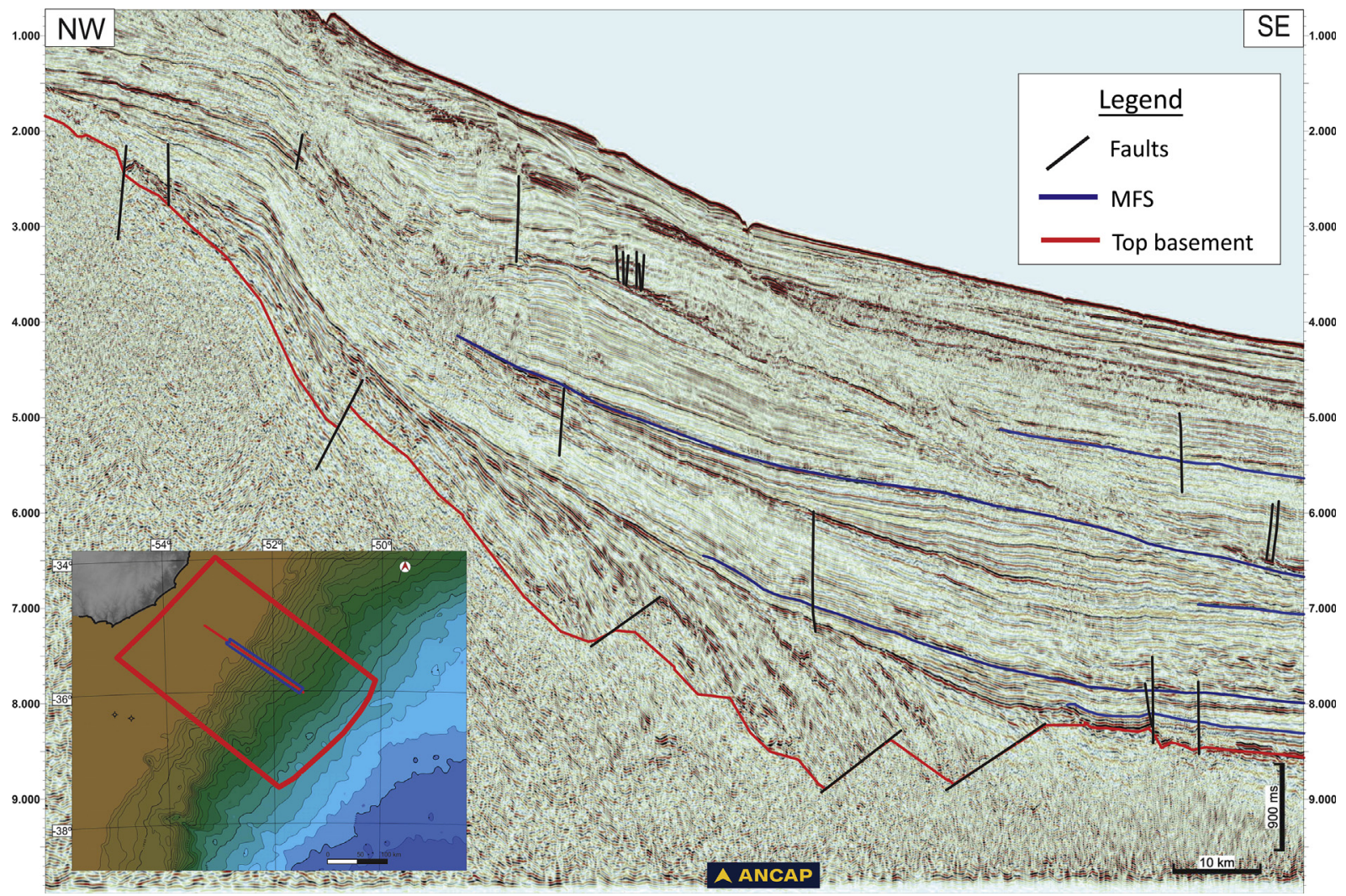

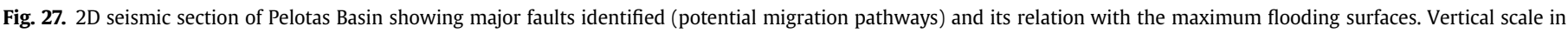
seconds (TWT). 


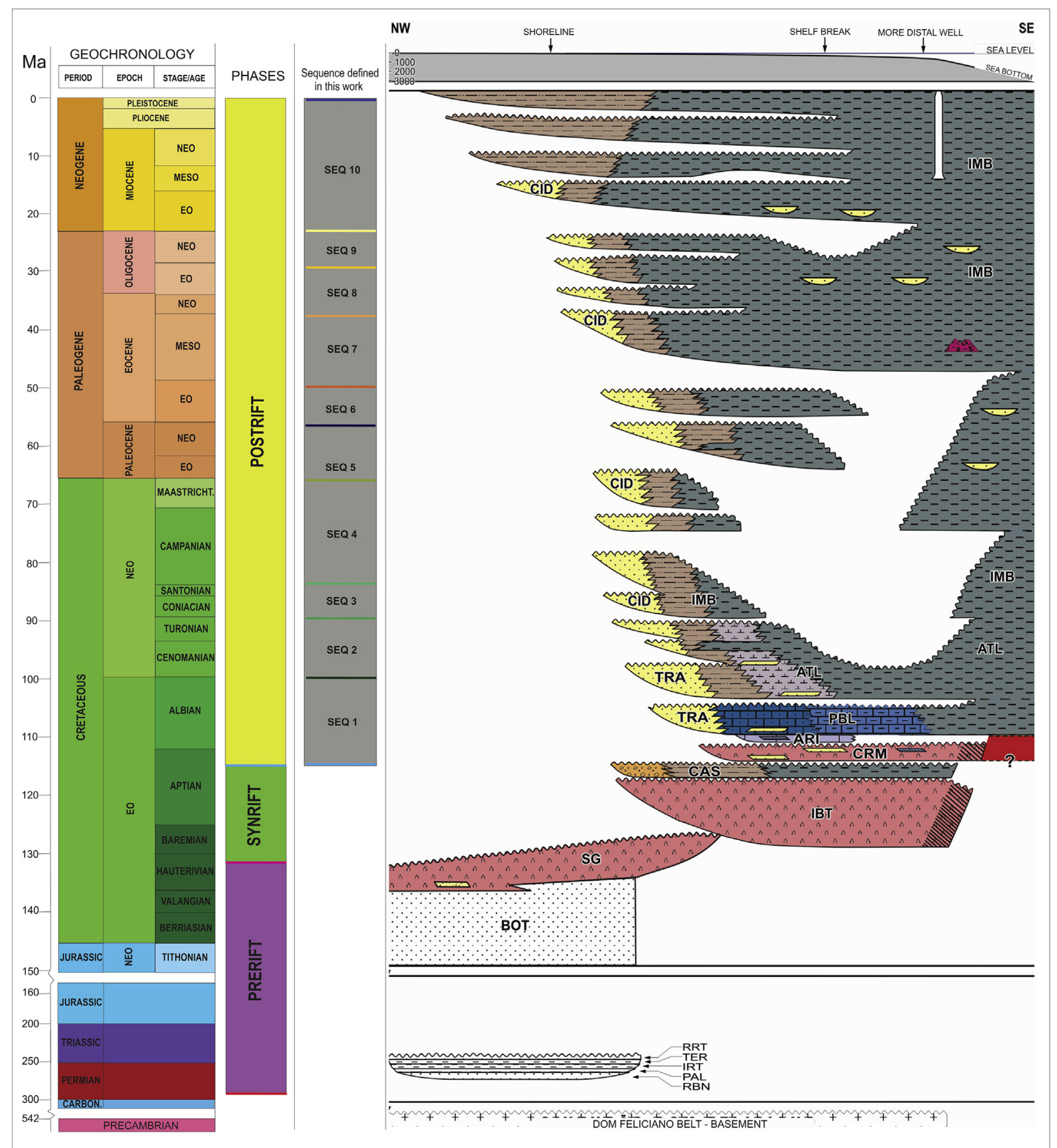

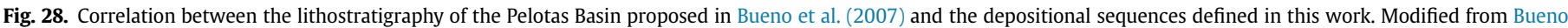
et al. (2007).

of reflectors is interpreted as a falling stage system tract. The isopach map shows that this sequence pinches out towards the continent and that the thickest sections are located in the west and east segments of the study area (Fig. 22). We attribute to this sequence a Campanian to Maastrichtian age. It is important to highlight the development of incised valleys as potential stratigraphic traps.

2.1.3.5. Depositional sequence 5 (Paleocene). Depositional sequence 5 developed in the distal region of the basin, and thins out in the proximal section against the previous sequence. This sequence is limited at its base by the SS4 and at the top by the SS5. In its distal section we recognize a set of reflectors with lobular geometry that lie against the previous sequence (Fig. 23). We interpret this feature as a submarine fan complex due to its paleogeographic location at the base of the paleoslope, its lobular morphology and its internal arrangement that presents downlap terminations on both sides of the body (Mitchum, 1985). This segment of the depositional sequence is interpreted as a lowstand system tract probably deposited in the Lower Paleocene during a period of relative fall of the sea level.

A set of continuous and parallel reflectors that present a retrogradational pattern onlaps against the LST and sequence 4 (Fig. 24). This set of reflectors represents a TST related to a relative rise of the sea level. The top of this TST is marked by a maximum flooding surface (MFS 3) related to a marine transgression probably developed during the Upper Paleocene. At the top of this tract we recognize a set of reflectors with a progradational stacking pattern that downlaps against the maximum flooding surface. We interpret 
this package as a HST. The isopach map shows that the thickest section developed in the central sector and has an elongated NESW trend (Fig. 25). This submarine fan complex, covered by marine transgression fine sediments, represents potential stratigraphic traps for hydrocarbons.

\subsection{Structural interpretation}

We performed a structural analysis of the area using available magnetic and seismic data for the study area. Analysis of the magnetic map (Reduced to Pole) allowed us to identify two main structural trends. The first trend, with a N10 ${ }^{\circ}$ direction, is associated with a set of faults that were likely generated in the initial phase of the fragmentation of Gondwana. This extensional phase developed the synrift phase (half-grabens and SDRs). The second trend has a $\mathrm{N} 260^{\circ}$ direction that is associated with a set of dextral faults that segments the first structural trend and were likely generated in a later phase. It is important to point out that potential hydrocarbon leakage can be enhanced in the areas of intersection between these two fault systems (Fig. 26). Our interpretations of the main faults and maximum flooding surfaces, allow us to visualize the relation between potential source rocks, potential seals and potential migration pathways for hydrocarbons (Fig. 27).

In our structural analysis of the seismic data, we identified the occurrence of sub-vertical faults, most of which affect the postrift section with displacement on the order of tens to hundreds of meters. Given the vertical orientation of the faults and the location of the fault systems identified, it is assumed that the potential Cretaceous source rocks (Aptian-Albian and Cenomanian-Turonian) fundamentally charged the Cretaceous and Lower Paleocene reservoirs, whereas the potential Paleocene source rock, if mature, charged (and continues to charge) mostly Cenozoic reservoirs.

\subsection{Proposed petroleum systems}

As a result of our seismostratigraphic analysis, we propose six speculative petroleum systems in the sense of Magoon and Dow (1994) for the study area:

\section{- IRATI-PIRAMBOIA/BOTUCATU(?) \\ - CASSINO-CASSINO(?) \\ - ATLÂNTIDA-IMBITUBA(?) \\ - ATLÂNTIDA-IMBE(?) \\ - Lower IMBE-IMBE(?) \\ - Middle IMBE-IMBE(?)}

It is important to note that an overburden model of the potential source rocks was not developed for this study. Therefore, in relation with the generation, migration and accumulation of hydrocarbons related with the different petroleum systems, we used overburden data of offshore Uruguay modeled by Morales (2013). We describe the elements that constitute each of the speculative petroleum

\section{GEOLOGICAL MODEL}

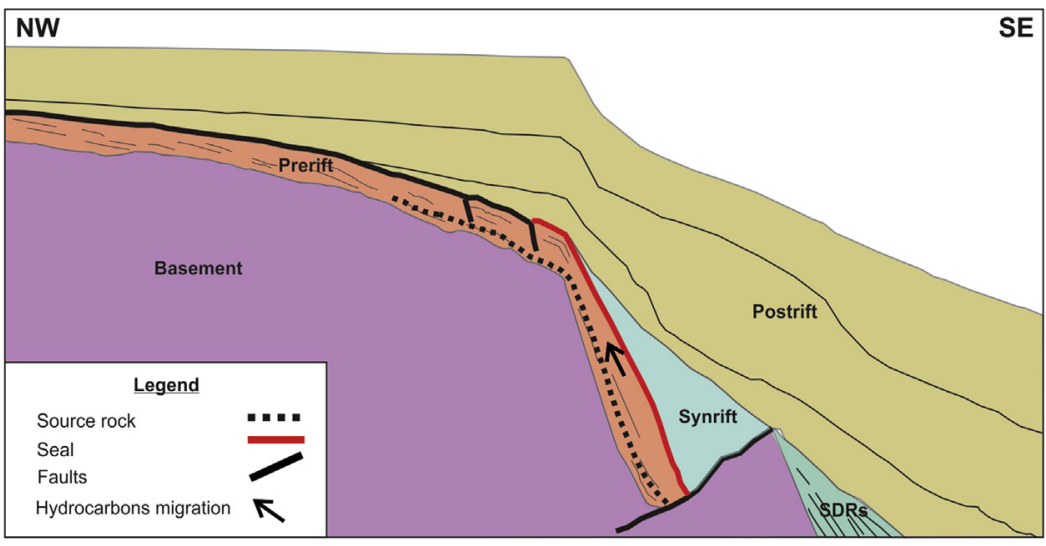

POTENTIAL PETROLEUM SYSTEM EXTENT

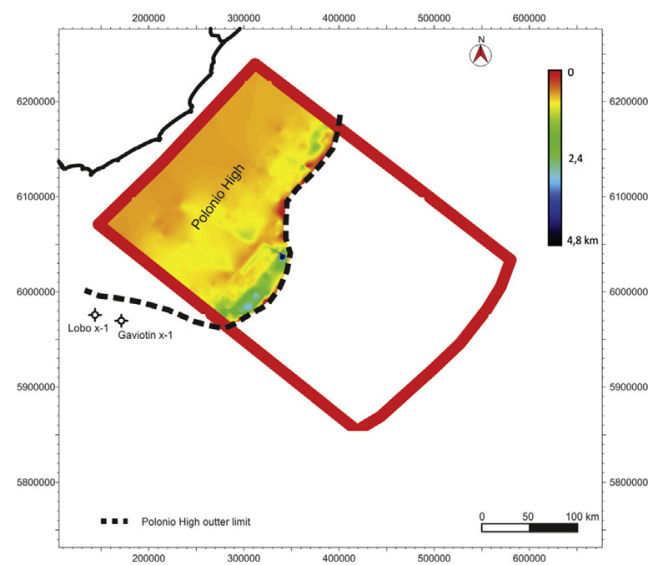

CHART OF EVENTS

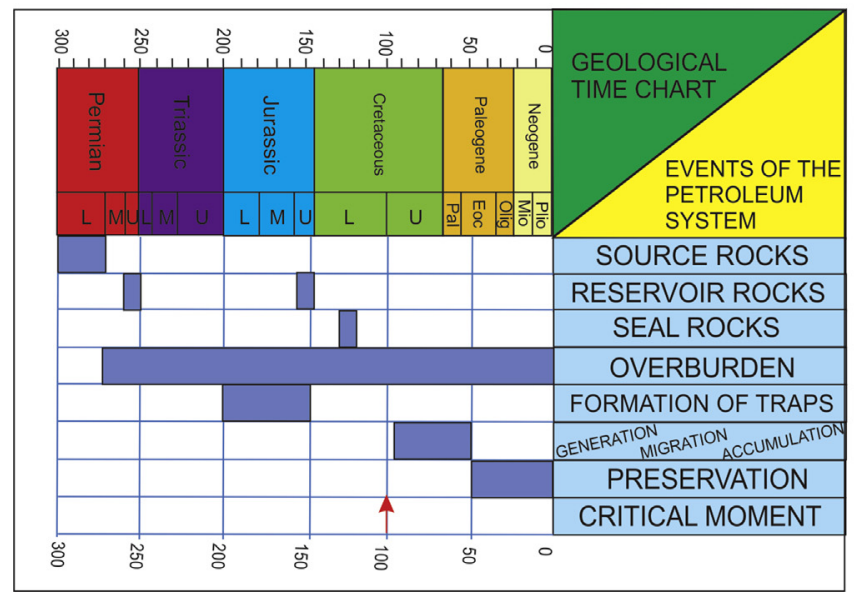

RELATED SEISMIC SECTION

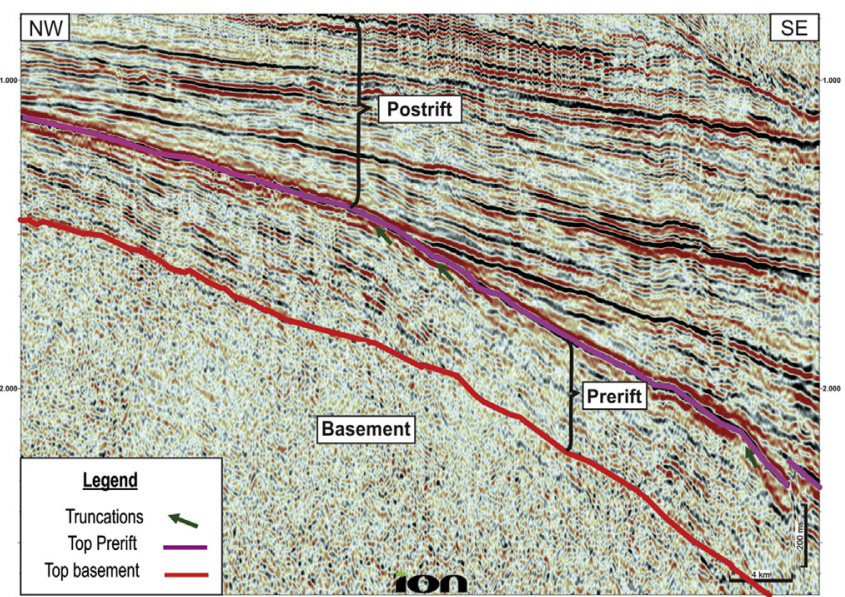

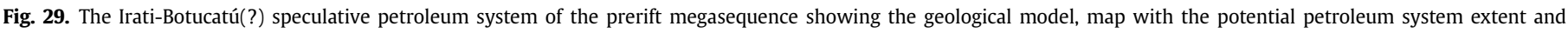
location of seismic section (black line). Also shown is the chart of events and a related seismic section. 
systems below. The naming of each speculative petroleum system (Fig. 28) follows the stratigraphy and formation names described for the Pelotas Basin by Bueno et al. (2007).

\subsubsection{Prerift related petroleum system: Irati-Botucatu(?)}

This Irati-Botucatu(?) speculative petroleum system is associated with the prerift megasequence. The source rock is comprised by Lower Permian organic-rich shales of the Irati Formation, which are interpreted as deposited in a restricted marine environment. The potential reservoirs are related to Permian to Upper Jurassic aeolian-fluvial sandstones of the Rio Bonito, Rio do Rasto, Piramboia and Botucatu formations. The seal for this system is comprised at least in part by Lower Cretaceous basalts of the Serra Geral Formation.

The distribution for this petroleum system is likely restricted to the proximal section of the study area (Fig. 29), and is strongly related to the distribution of the Polonio High. The identified traps for this petroleum system are mainly structural, related to faults generated during crustal deformation in the synrift phase. In the context of the Parana Basin, the Irati Formation (Mangrullo Formation in Uruguay) is predominantly immature, only reaching the oil/gas window when it is associated with magmatic intrusions. However, in the study area the Irati shale would have reached maturity due to the additional overburden associated with the

\section{GEOLOGICAL MODEL}

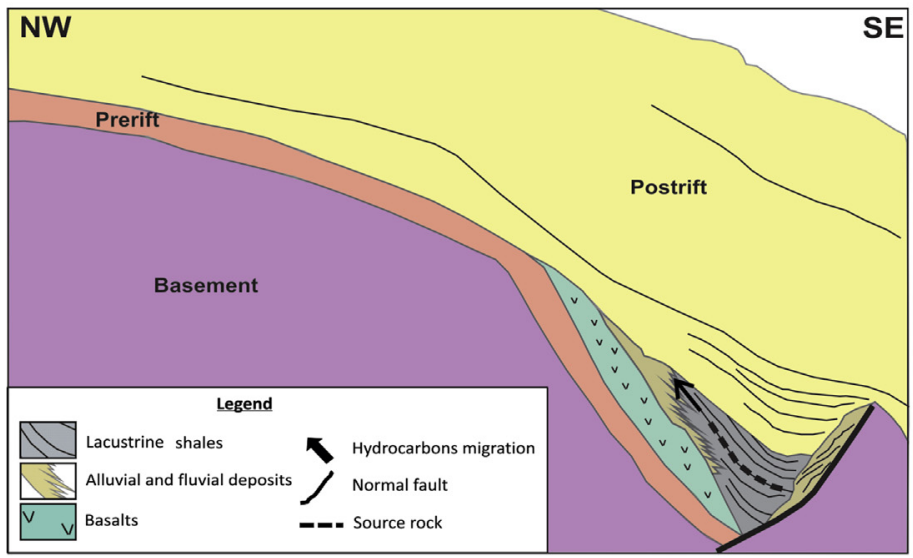

CHART OF EVENTS

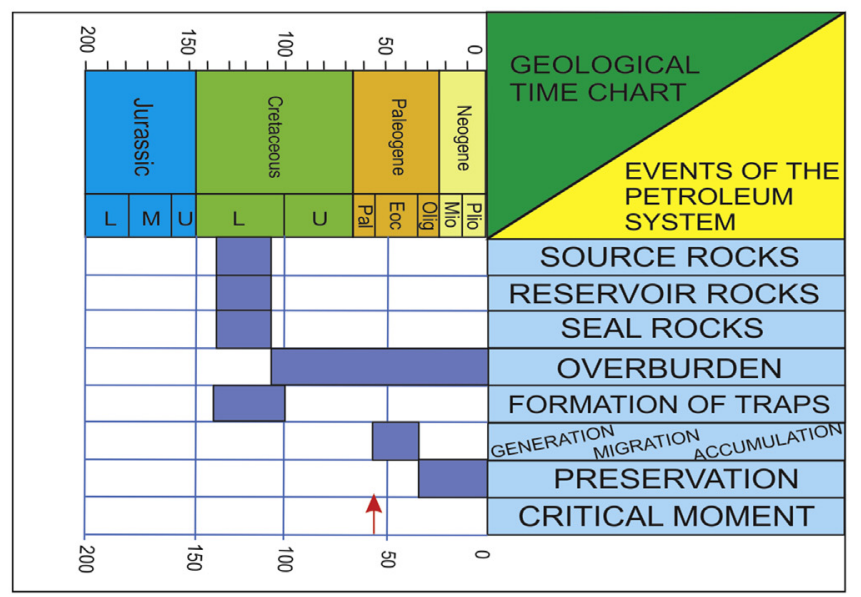

synrift and postrift sediments of the Pelotas Basin. The migration of the generated hydrocarbons from the source to the reservoir only represents a distance of hundreds of meters and would follow subvertical faults.

There are several risks associated with this petroleum system, among them the integrity of the traps. The fundamental risk, however, is related to the preservation of the different elements of the petroleum system (source rock, reservoir, seal) as the seismic resolution does not allow us to individualize system tracts.

\subsubsection{Synrift related petroleum systems}

2.3.2.1. Cassino-Cassino(?). The Cassino-Cassino(?) speculative petroleum system is related with the synrift megasequence, restricted to the development of half-grabens. The potential source rock is comprised of Barremian lacustrine shales (tentatively associated with the Cassino Formation), whereas the reservoirs are associated with alluvial deposits of the Cassino Formation. The seal is represented by the same lacustrine shales that are interbedded with the alluvial deposits, and also by volcanic rocks of the Imbituba Formation. This petroleum system is restricted to the western portion of the area (Fig. 30), with the identified traps consisting of stratigraphic pinchouts and alluvial fans deposited in lacustrine environments.

Potential petroleum migration would be direct, as the lacustrine

\section{POTENTIAL PETROLEUM SYSTEM EXTENT}

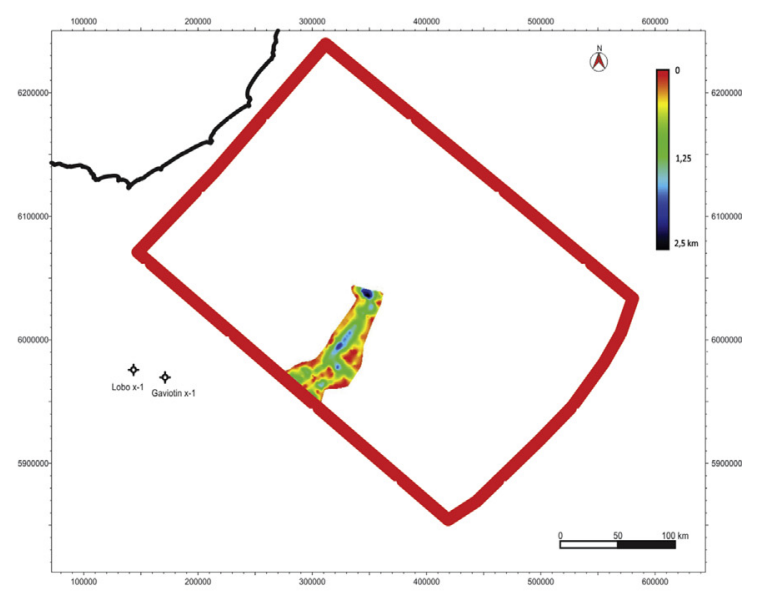

RELATED SEISMIC SECTION

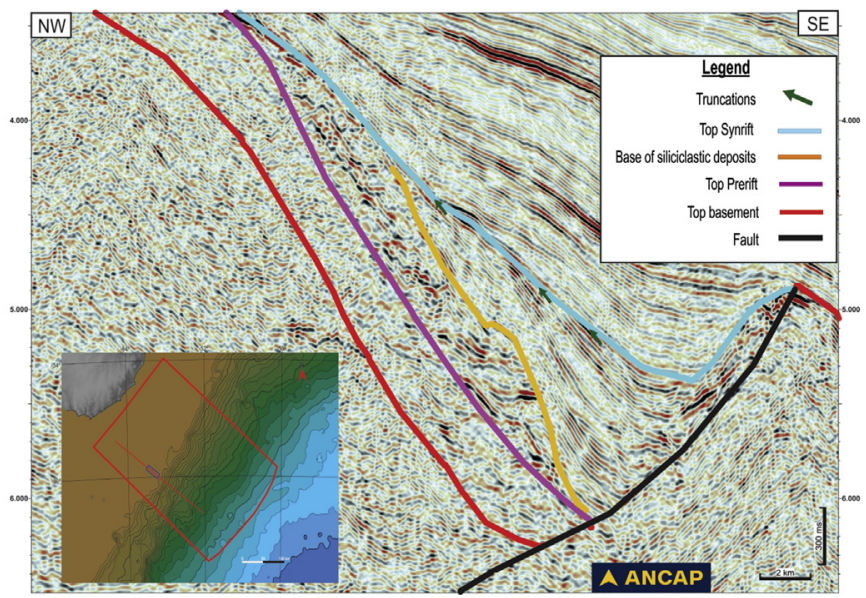

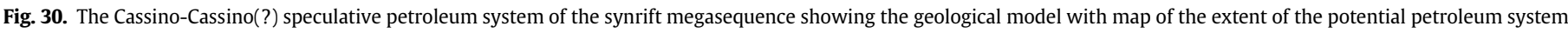
and location of the seismic section (black line). Also shown is the chart of events and a related seismic section. 
source rock and the alluvial reservoirs are in contact. The main risk associated with this petroleum system is the presence of the source rock that, although potentially recognized on seismic, had not been drilled by wells. Additionally, the extent of the half-grabens in the study area is only approximately $3 \mathrm{~km}^{2}$, therefore reducing the generation potential.

2.3.2.2. Atlântida-Imbituba(?). The source rock for this speculative petroleum system is represented by Aptian-Albian marine shales of the Atlântida Formation, which are distributed in the distal portion of the basin. These shales were deposited during the first oceanic anoxic event of the Cretaceous (OAE 1) (Schlanger and Jenkyns, 1976) during the beginning of the postrift stage. The reservoirs are related with the SDR package associated with the late synrift phase, represented by aeolian sands interbedded with lava flows of the Imbituba Formation (we use the same name of the slightly older volcanic rocks which fills the half-grabens). The seal is formed by the same lava flows that, together with the aeolian sands, form stratigraphic pinchouts. The Kudu Gas Field in the Orange Basin of offshore Namibia serves as an analog for this geological model (Bray and Lawrence, 1999). The main risk associated with this petroleum system is the presence of the clastic reservoir in the SDRs. If present, the clastic intertraps would manifest in the proximal section of the SDRs, whereas the distal portion would be comprised fundamentally of volcanic rocks. Considering that the Aptian source rock is onlapping the SDRs sequence (Fig. 31), the migration of hydrocarbons would be expected to take place through the unconformities between these units.

\subsubsection{Postrift related petroleum systems}

2.3.3.1. Atlântida-Imbé(?). The Atlântida-Imbé(?) speculative petroleum system presents a source rock of Aptian-Albian age which corresponds to marine shales deposited during the OAE 1 of the Atlântida Formation. In this case, the reservoirs are represented by Upper Cretaceous sandstones beds associated with deltaic progradation fronts and, most notably, turbidites of the Imbé Formation. The seals are associated with maximum flooding surfaces registrated during the Cenomanian-Turonian and Upper Paleocene, that deposited fine-grain facies of the Imbé Formation (marine shales) that covered the potential reservoirs. The Atlântida-Imbé(?) system developed in the distal portion of the study area (Fig. 32). One of the main risks associated with this petroleum system is related with the presence of migration paths (faults) that effectively connects the Aptian source rock with the clastic reservoirs of the Imbé Formation.

\section{GEOLOGICAL MODEL}

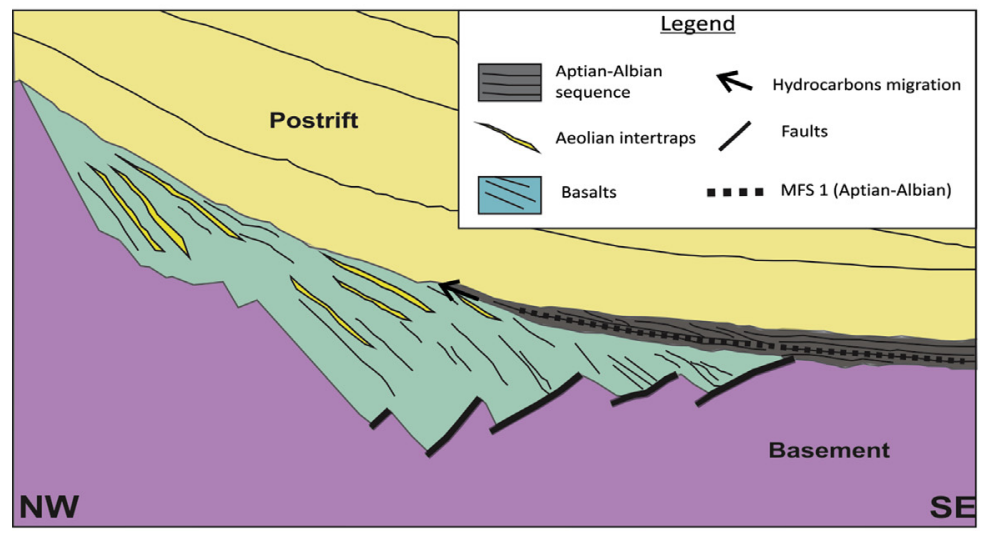

\section{POTENTIAL PETROLEUM SYSTEM EXTENT}

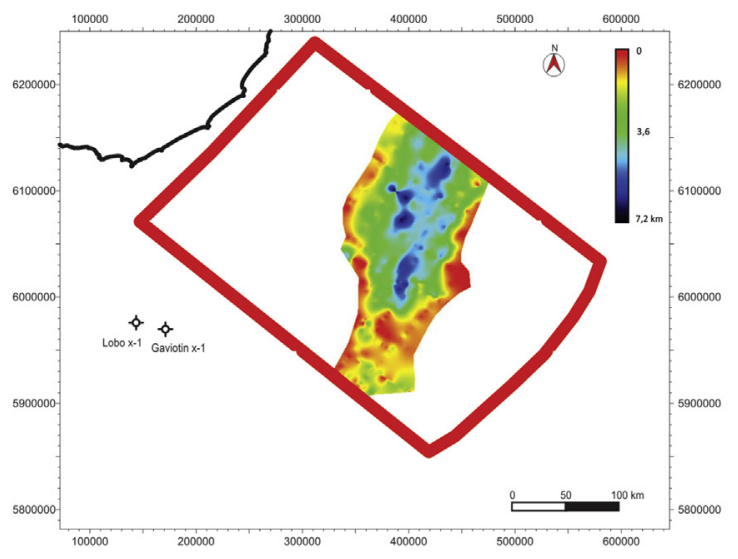

RELATED SEISMIC SECTION

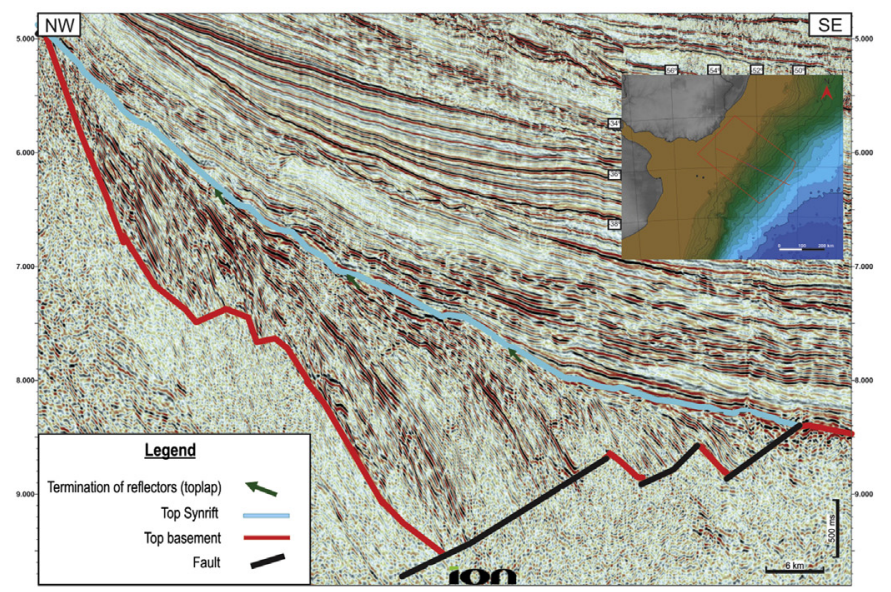

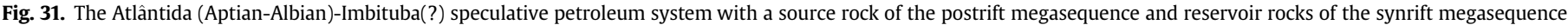

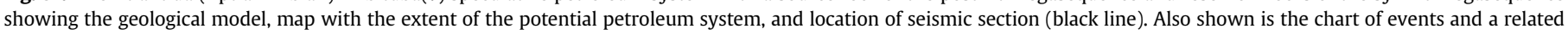
seismic section. 
GEOLOGICAL MODEL

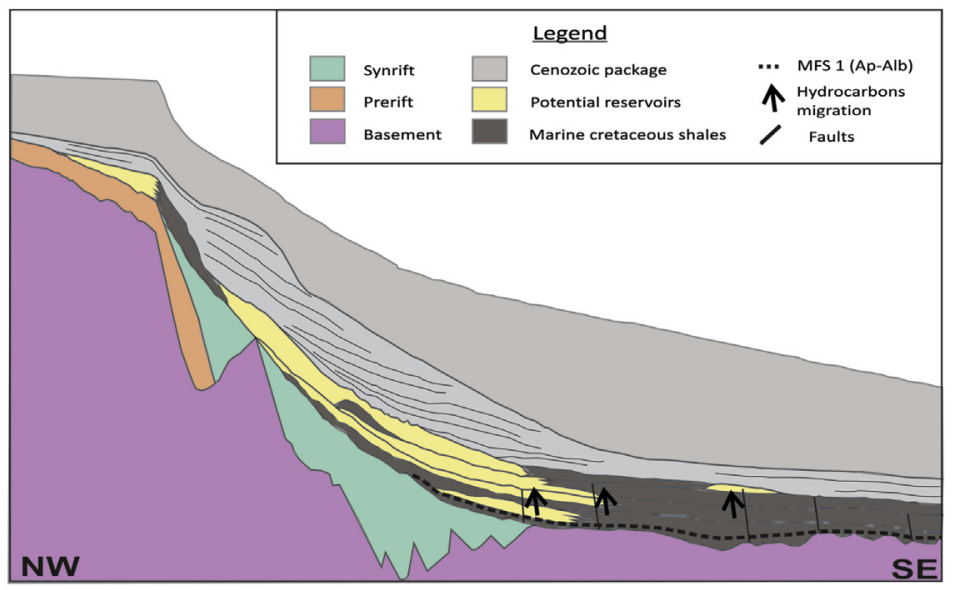

POTENTIAL PETROLEUM SYSTEM EXTENT

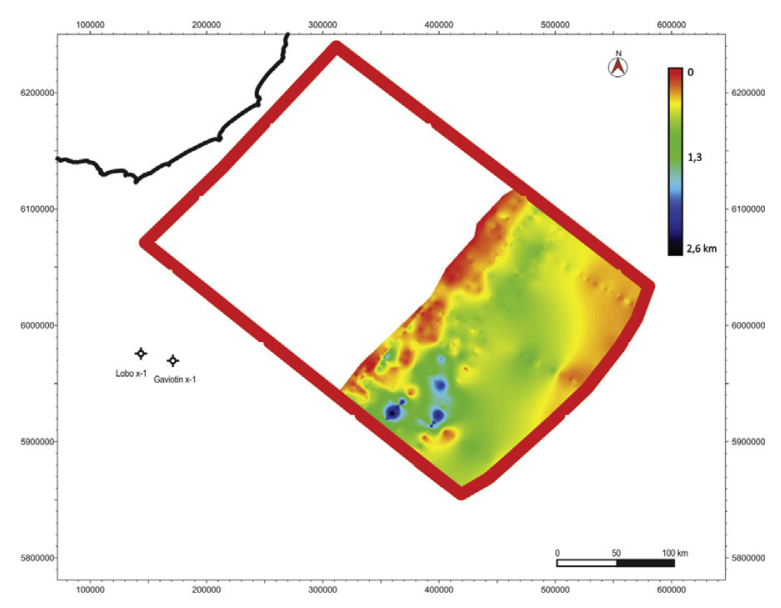

RELATED SEISMIC SECTION
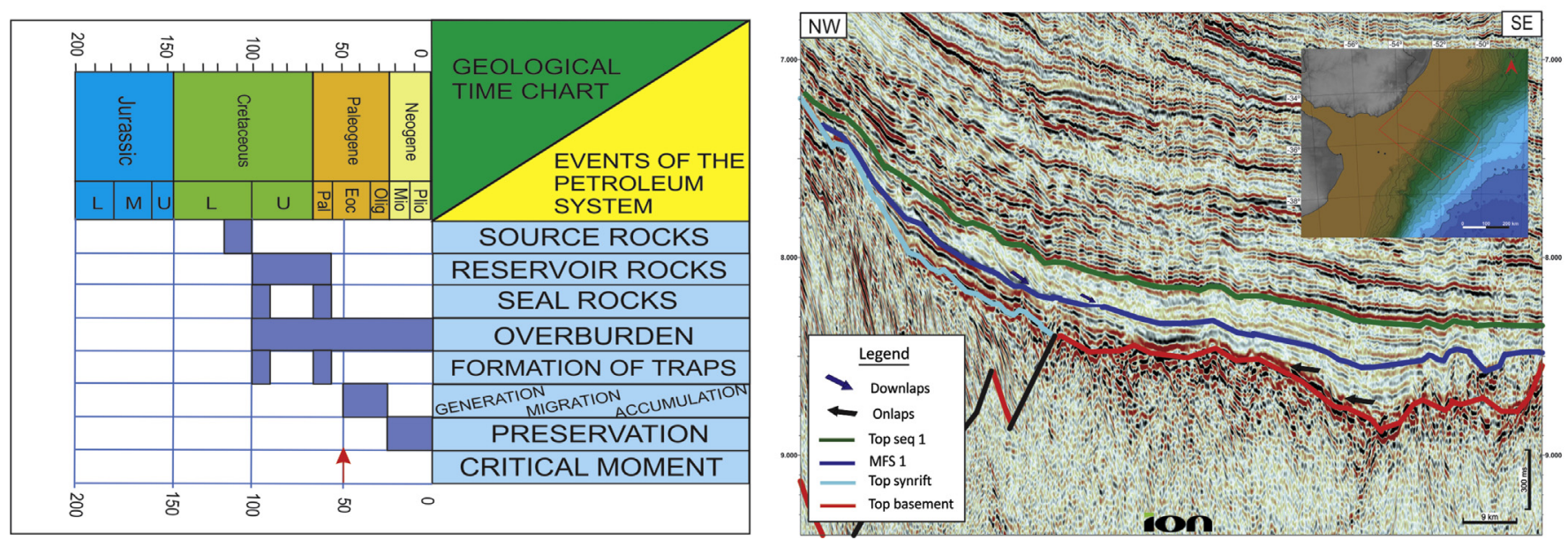

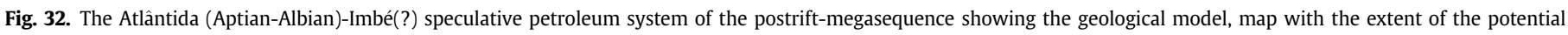
petroleum system, and location of seismic section (black line). The chart of events and a related seismic section are also shown.

2.3.3.2. Lower Imbé-Imbé(?). The Lower Imbé-Imbé(?) speculative petroleum system contains source rocks of Cenomanian-Turonian age, which correspond to marine shales within the lower section of the Imbé Formation. These shales were deposited during the second oceanic anoxic event of the Cretaceous (OAE2). The reservoirs are represented by Upper Cretaceous and Lower Paleocene sandstone beds associated with deltaic progradation fronts and turbidites of the Imbé Formation. The marine shales of the Imbé Formation are related to the Upper Paleocene transgression, where we identify a MFS that could serve as seals for the sandstones. The migration of hydrocarbons would be direct (laterally), or vertically through faults that connect the fine-grain facies with the coarsegrain facies of the Imbé Formation (Fig. 33). The main risk related with this petroleum system, as with the previous case, is the presence of effective migration paths that connect the source to the reservoirs.

2.3.3.3. Middle Imbé-Imbé(?). The Middle Imbé-Imbé(?) speculative petroleum system developed in the upper section of the postrift megasequence and presents a source rock of Paleocene marine shales belonging to the middle section of Imbé Formation.
The reservoirs are fundamentally represented by turbidites, channel infills and progradation fronts deposited in the Eocene, Oligocene and Miocene. This system developed in the distal portion of the study area (Fig. 34). The MFS identified for the Lower Eocene and Lower Miocene represent marine shales that could act as regional seals. The main risk related with this system is the quality and maturation of the source rock, considering that the Paleocene sequence is immature in the proximal sector of the Brazilian segment of the basin where it was drilled (ANP, 2004). However, this source rock could enter (be within) the oil window in the distal section where the overburden is thicker (Morales, 2013). The ultradeep Raya-1 well, drilled in Pelotas Basin (offshore of Uruguay) tested this petroleum system, being the main objective a tertiary basin floor fan (Spectrum, 2015). According to ANCAP (2016), this well reached a high porosity $135 \mathrm{~m}$ sand body of good porosity although, no oil accumulations were found.

\section{Conclusions}

We performed a seismostratigraphic interpretation of 2D seismic sections of the Uruguayan portion of the Pelotas Basin and 
GEOLOGICAL MODEL

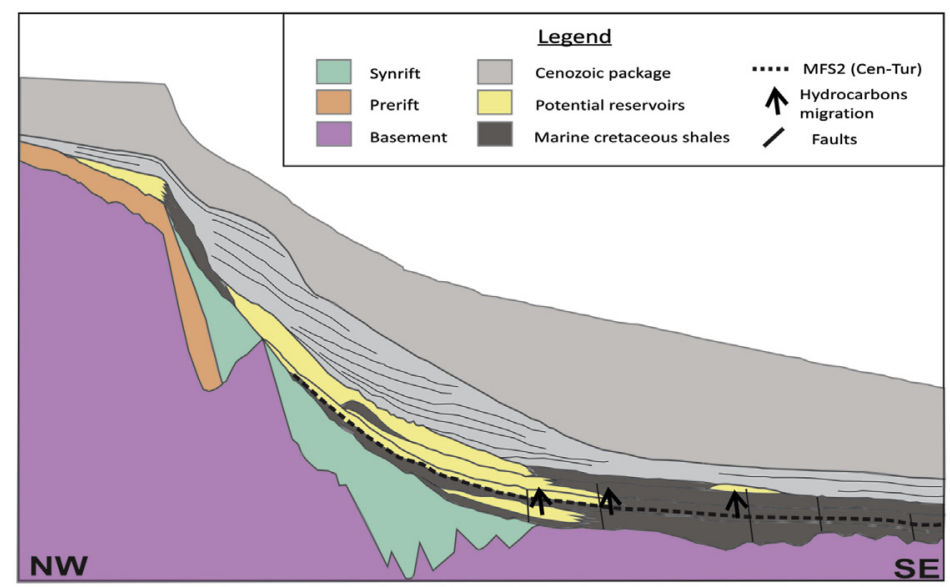

POTENTIAL PETROLEUM SYSTEM EXTENT

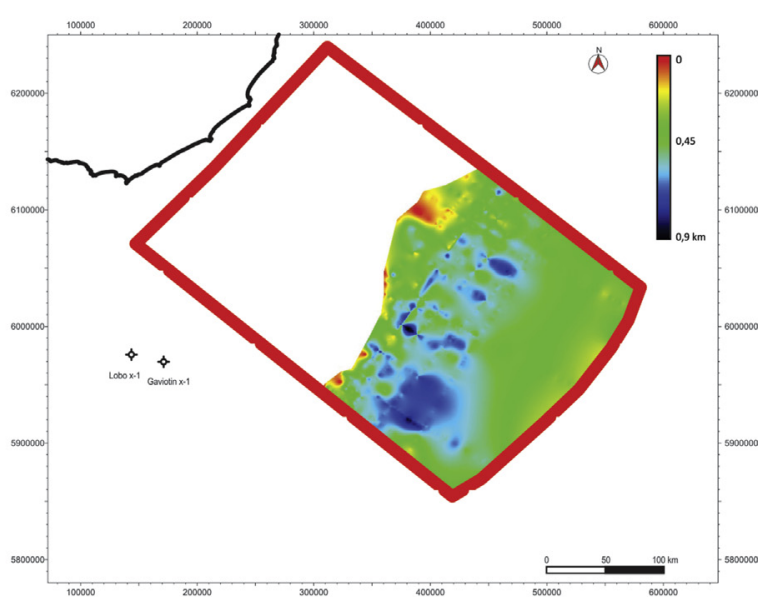

RELATED SEISMIC SECTION

CHART OF EVENTS
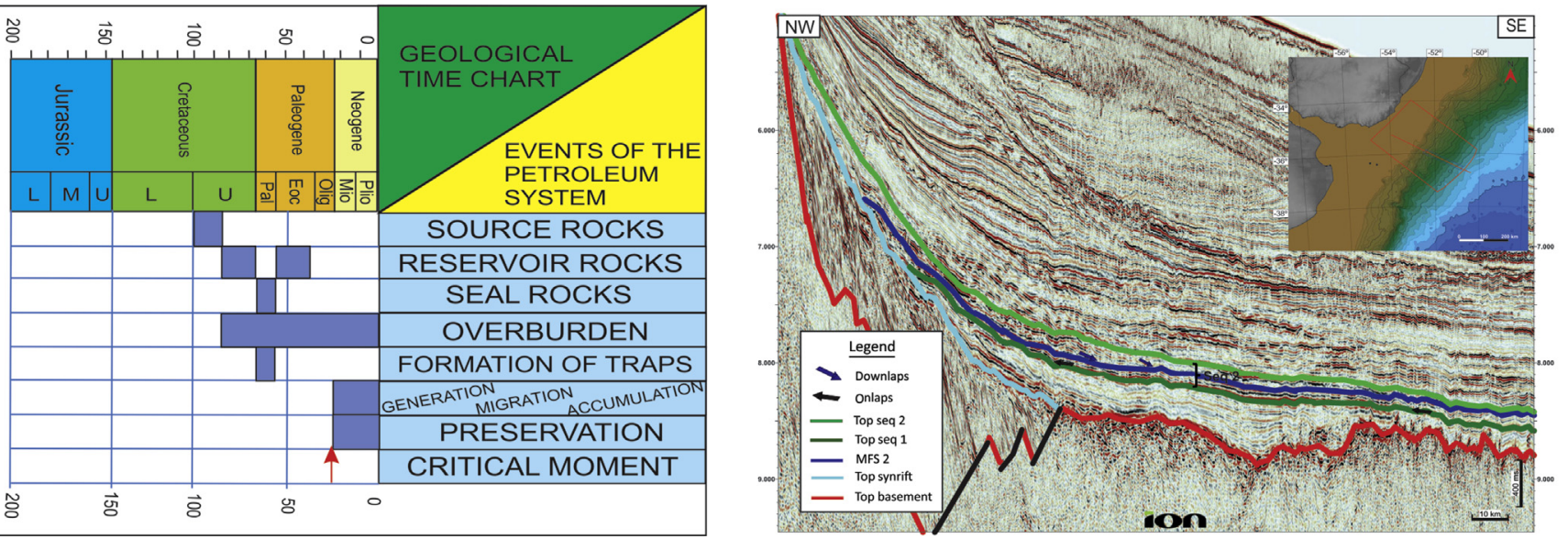

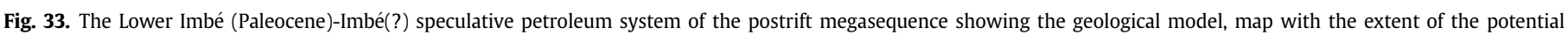
petroleum system, and location of seismic section (black line). Also shown is a chart of events and a related seismic section.

conclude that the region shows a favorable geology for the accumulation of hydrocarbons, in this still under-explored basin. In the study area, we identified 3 megasequences that constitute the volcanic-sedimentary infill of the basin: prerift, synrift and postrift, the latter composed by 10 depositional sequences. Potential sources, reservoirs and seal rocks in the three megasequences were identified with six proposed speculative petroleum systems: one related with the prerift; one with the synrift; and four with the postrift megasequence. It is important to note that the prerift petroleum system represents the superimposition in the onshore/ nearshore portion of the Pelotas Basin of a proven petroleum system of the Parana Basin. The half-graben related petroleum system of the synrift megasequence presents a distribution that is restricted to the proximal sector, providing the main risk related to the development of potential lacustrine source rock. On the other hand, the SDR related petroleum system has a potentially widespread Aptian-Albian source rock, with the main risk being the presence of high-quality reservoirs. The reservoirs of this proven petroleum system in the Orange Basin of offshore Namibia are aeolian sandstones interbedded with volcanic rocks.

In the postrift megasequence, we identified three potential marine source rocks related to maximum flooding surfaces: two of them (Aptian-Albian and Cenomanian-Turonian) are world-class source rocks. The organic content of these pelagic sequences is expected to increase in a more distal location of the basin. We identified multiple siliciclastic reservoirs for the postrift megasequence, fundamentally in the Upper Cretaceous and Paleogene. We also identified regional seals associated with the maximum flooding surfaces that deposited shales during marine transgressions in the Cenomanian-Turonian, Paleocene and Miocene. These observations support the conclusion that the postrift petroleum systems present a higher hydrocarbon potential compared to those of the prerift and synrift megasequences. These speculative postrift petroleum systems developed fundamentally in the distal part of the study area. With few exceptions, the majority of the traps identified are stratigraphic types: pinchouts, turbidites and channels. Our structural analyses identified a set of subvertical faults in the postrift section, which could potentially act as migration pathways for hydrocarbons. The vertical extension of the faults allows us to affirm that the Lower Cretaceous source rocks would have fed fundamentally Cretaceous reservoirs, whereas the Paleocene source rock, if mature, would have fed the Cenozoic reservoirs. The migration pathways, however, are apparently one of the critical factors for the formation of hydrocarbon accumulations. 
GEOLOGICAL MODEL

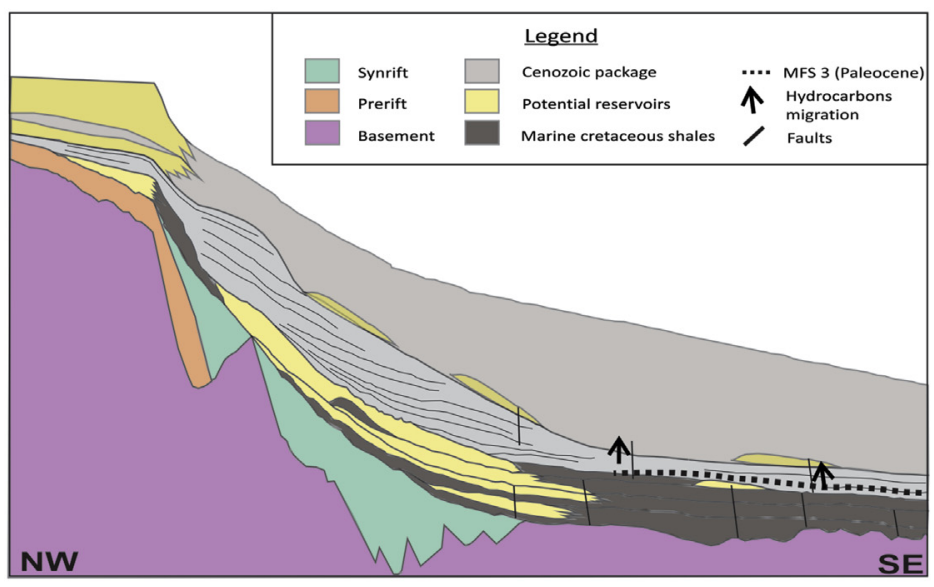

CHART OF EVENTS
POTENTIAL PETROLEUM SYSTEM EXTENT

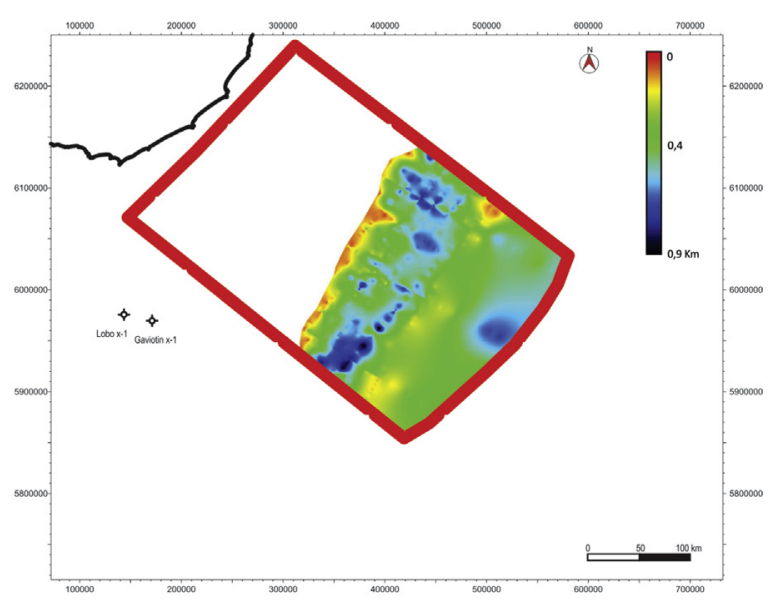

RELATED SEISMIC SECTION
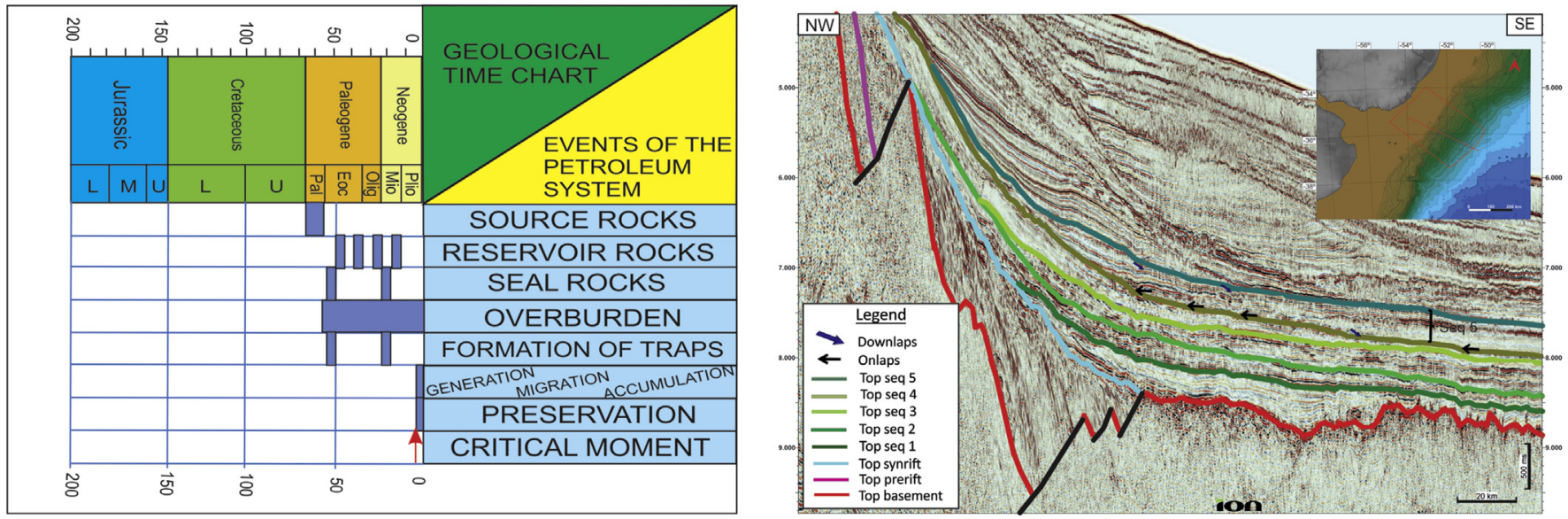

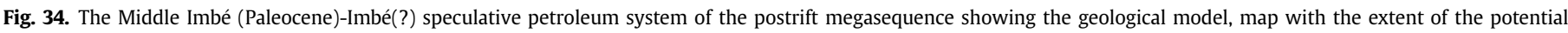
petroleum system, and location of seismic section (black line). Also shown is a chart of events and a related seismic section.

\section{Acknowledgments}

This article is a product of a Master of Science thesis carried out by B.C. at UNESP University, Campus of Rio Claro/SP. We would like to thank to all the professors at UNESP University. Thanks to ANCAP for supporting the thesis, to ION GXT for allowing the use of the seismic lines and Rodri Novi for the help with the images. Special thanks to Morgan J. Salisbury for his invaluable contributions that helped improve this article. Finally, we would like to thank the reviewers for their valuable comments and suggestions, which improved this manuscript.

\section{References}

ANP (Agencia Nacional do Pétroleo, 2004. Brasil Round 4: Pelotas Basin. Gas Natural e Biocombustíveis. http://www.anp.gov.br/brasil-rounds/round4/round4/ workshop/restrito/ingles/Pelotas_ing.pdf (Accessed 20 November 2016).

ANCAP (Administración Nacional de Combustibles Alohol y Portland), 2016. Press Release: Culmination of Exploratory Well Raya X-1 on Area 14 Offshore Uruguay. http://www.rondauruguay.gub.uy/LinkClick.aspx? fileticket $=$ rIctbj30FrE\%3d\&tabid $=474$. August (Accessed 01 February 2017).

ANP (Agência Nacional do Petróleo, 2015. Décima Terceira Rodada de Licitaçoēs. Bacia de Pelotas. Sumário Geológico e Setores em Oferta. Gás Natural e Biocombustíveis.

Bray, R., Lawrence, S., 1999. Nearby Find Brighten Outlook. The Leading Edge. May Issue, pp. 806-814.

Bryant, I., Herbst, N., Dailly, P., Dribus, J.R., Fainstein, R., Harvey, N., McCoss, A.,
Montaron, B., Quirk, D., Tapponier, D., 2012. Basin to basin: plate tectonics exploration. Oil Rev. 24, 3.

Bueno, G.V., Zacharias, A.A., Oreiro, S.G., Cupertino, J.A., Falkenhein, F.U.H. Neto, M.A.M., 2007. Bol. Geociências Petrobras, Rio J. 15 (2), 551-559.

Cainelli, C., Mohriak, W.U., 1999. Some remarks on the evolution of sedimentary basins along the eastern Brazilian continental margin. Episodes 22 (3), 206-215.

Catuneanu, O., 2006. Principles of Sequence Stratigraphy. Elsevier Science Ltd Amsterdam.

Dias, J.L., Sad, A.R.E., Fontana, R.L., Feijó, F.J., 1994. Rio de Janeiro. Bacia de Pelotas Boletim de Geociências da Petrobras, vol. 8, pp. 235-245.

Fontana, R.L., 1987. Desenvolvimento termomecânico da Bacia de Pelotas e parte sul da Plataforma de Florianópolis. Dissertação de Mestrado, Universidade Federal de Ouro Preto, Minas Gerais.

Fontana, R.L., 1996. Geotectônica e sismoestratigrafia da Bacia de Pelotas e Plataforma de Florianópolis. Tese de doutorado em Geociências. Universidade Federal do Rio Grande do Sul, Porto Alegre.

Franke, D., Neben, S., Ladage, S., Schreckenberger, B., Hinz, K., 2007. Margin segmentation and volcano-tectonic architecture along the volcanic margin off Argentina/Uruguay, South Atlantic. Mar. Geol. 244 (1-4), 46-67.

França, A.B., Milani, E.J., Schneider, R.L., López, O., López, J., Suárez, R., Santa Ana, H. Wiens, F., Ferreiro, O., Rosello, E.A., Bianucci, H.A., Flores, R.F.A. Vistalli, M.C. Fernandez-Seveso, F., Fuenzalida, R.P., Muñoz, N., 1995. Phanerozoic correlation in southern south America. AAPG 62. In: Tankard, A.J., Suárez, R., Welsink, H.J (Eds.), Petroleum Basins of South America, pp. 129-161.

Hardenbol, J., Thierry, J., Farley, M.B., Jacquin, T., de Graciansky, P.C., Vail, P., 1998 Mesozoic and Cenozoic sequence chronostratigraphic framework of European basins. SEPM Special Pub. In: Graciansky, P.C., et al (Eds.), Mesozoic and Cenozoic Sequence Stratigraphy of European Basins, vol. 60, pp. 3-13. charts 18.

Hubbard, R.J., Pape, J., Roberts, D.G., 1985. Depositional sequence mapping as a 
technique to establish tectonic and stratigraphic framework and evaluate hydrocarbon potential on passive continental margin. AAPG 39. In: Berg, O.R. Woolverton, D.G. (Eds.), Seismic Stratigraphy II: an Integrated Approach, pp. 79-92.

Lobo, J.T., 2007. Petrogênese das rochas basálticas do eocretáceo das Bacias de Campos e Pelotas e implicações na geodinâmica de rifteamento do Gondwana Ocidental. Tese Doutorado - Universidade do Estado do Rio de Janeiro, Rio de Janeiro.

Magoon, L.B., Dow, G.W., 1994. The petroleum system. AAPG, 60. In: Magoon, L.B., Dow, W.G. (Eds.), The Petroleum System-from Source to Trap, pp. 3-24.

Milani, E.J., França, A.B., Schneider, R.L., 1994. Bacia de Paraná. Bol. Geociências Petrobras 8, 69-82.

Mitchum Jr., R.M., 1985. Seismic stratigraphic expression of submarine fans. AAPG, 39, Tulsa. In: Berg, O.R., Woolverton, E.G. (Eds.), Seismic Stratigraphy II: an Integrated Approach to Hydrocarbon Exploration, pp. 117-136.

Morales, E., 2013. Evolução tectônica e estratigráfica das bacias da margem continental do Uruguai. Tese de Doutorado, Rio Claro.

Moulin, M., Aslanian, D., Olivet, J.L., Contrucci, I., Matias, L., Géli, L., Klingelhoefer, F. Nouzé, H., Réhault, J.P., Unternehr, P., 2005. Geological constraints on the evolution of the Angolan margin based on reflection and refraction seismic data (ZaïAngo project). Geophys. J. Int. 162, 793-810.

Paton, D.A., Di Primio, R., Kuhlmann, G., Van Der Spuy, D., Horsfield, B., 2007. Insights into the petroleum systems evolution of the southern Orange Basin,
South Africa. South Afr. J. Geol. 110, 261-274.

Porto, R., Asmus, H.E., 1976. The Brazilian marginal basins - current state of knowledge. An. Acad. Bras. Ciências 48, 215-240.

Schlanger, S.O., Jenkyns, H.C., 1976. Cretaceous oceanic anoxic events: causes and consequences. Geol. Mijnb. 55, 179-184.

Snedden, J.W., Liu, C., 2010. A Compilation of Phanerozoic Sea-Level Changes, Coastal Onlaps and Recommended Sequence Designations. Article \# 40594 Search Discov.

Soto, M., Morales, E., Veroslavsky, G., De Santa Ana, H., Ucha, N., Rodriguez, P., 2011. The continental margin of Uruguay: crustal architecture and segmentation. Mar. Petroleum Geol. 28, 1676-1689.

Spectrum, 2015. Uruguay: Raya-1 First Offshore, Record-breaking Deep Water Well to Be Drilled. More to come? http://www.spectrumgeo.com/press-release exxon-and-total-join-forces-to-drill-uruguays-1st-offshore-record-breakingdeep-water-well. November, 2015 (Accessed 1 February 2017).

Stica, J.M., Zalán, P.V., Ferrari, A.L., 2014. The evolution of rifting on the volcanic margin of the Pelotas Basin and the contextualization of the Paraná-Etendeka LIP in the separation of Gondwana in the South Atlantic. Mar. Petroleum Geol. $50,1-21$.

Ucha, N., de Santa Ana, H., Veroslavsky, G., 2004. La Cuenca Punta del Este: geología y potencial hidrocarburífero. In: Veroslavsky, G., Ubilla, M., Martínez, S. (Eds.), Cuencas Sedimentarias de Uruguay: Geología, Paleontología y recursos naturales del Mesozoico. DIRAC, Montevideo, pp. 173-192. 